\title{
Structural Conformers of (1,3-Dithiol-2-ylidene)ethanethioamides: The Balance Between Thioamide Rotation and Preservation of Classical Sulfur-Sulfur Hypervalent Bonds
}

Pedro Fuertes, Maria Garcia-Valverde, Ricardo Pascual, Teresa Rodriguez, Josefa Rojo, Jose Garcia-Calvo, Patricia Calvo, José Vicente Cuevas, Gabriel García-Herbosa, and Tomas Torroba

J. Org. Chem., Just Accepted Manuscript • DOI: 10.1021/jo501473z • Publication Date (Web): 21 Nov 2014

Downloaded from http://pubs.acs.org on December 1, 2014

\section{Just Accepted}

"Just Accepted" manuscripts have been peer-reviewed and accepted for publication. They are posted online prior to technical editing, formatting for publication and author proofing. The American Chemical Society provides "Just Accepted" as a free service to the research community to expedite the dissemination of scientific material as soon as possible after acceptance. "Just Accepted" manuscripts appear in full in PDF format accompanied by an HTML abstract. "Just Accepted" manuscripts have been fully peer reviewed, but should not be considered the official version of record. They are accessible to all readers and citable by the Digital Object Identifier (DOI®). "Just Accepted" is an optional service offered to authors. Therefore, the "Just Accepted" Web site may not include all articles that will be published in the journal. After a manuscript is technically edited and formatted, it will be removed from the "Just Accepted" Web site and published as an ASAP article. Note that technical editing may introduce minor changes to the manuscript text and/or graphics which could affect content, and all legal disclaimers and ethical guidelines that apply to the journal pertain. ACS cannot be held responsible for errors or consequences arising from the use of information contained in these "Just Accepted" manuscripts. 


\title{
Structural Conformers of (1,3-Dithiol-2-ylidene)ethanethioamides: The Balance Between Thioamide Rotation and Preservation of Classical Sulfur-Sulfur Hypervalent Bonds.
}

Pedro Fuertes, María García-Valverde, Ricardo Pascual, Teresa Rodríguez, Josefa Rojo, José García-Calvo, Patricia Calvo, José V. Cuevas, Gabriel García-Herbosa, and Tomás Torroba* Department of Chemistry, Faculty of Sciences, University of Burgos, 09001 Burgos, Spain. ttorroba@ubu.es.

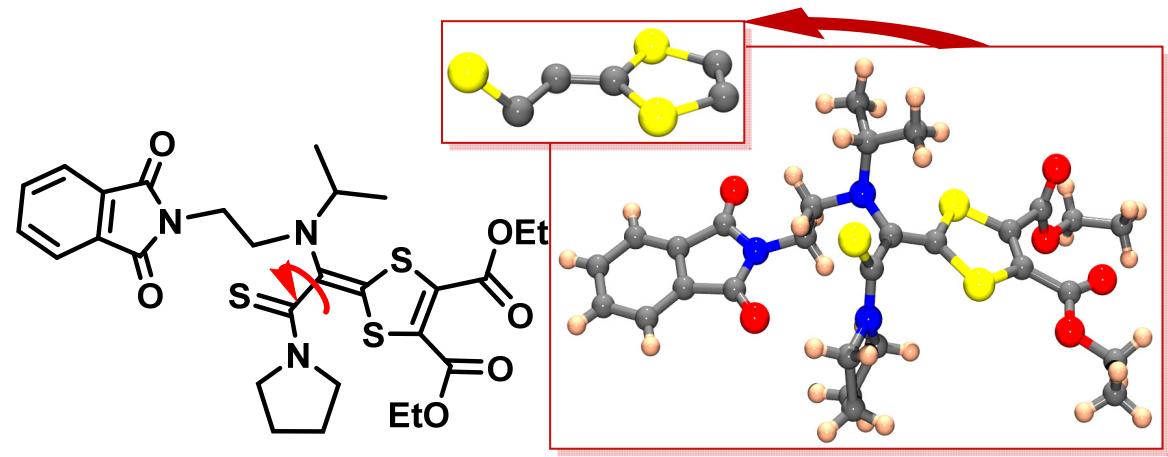

\begin{abstract}
The reaction of $N$-(2-phthalimidoethyl)- $N$-alkylisopropylamines and $\mathrm{S}_{2} \mathrm{Cl}_{2}$ gave 4$N$-(2-phthalimidoethyl)- $N$-alkylamino-5-chloro-1,2-dithiol-3-thiones that quantitatively cycloadded to dimethyl or diethyl acetylenedicarboxylate to give stable thioacid chlorides, which in turn reacted with one equivalent of aniline or a thiole to give thioanilides or a dithioester. Several compounds of this series showed atropisomers that were studied by a combination of dynamic NMR, simulation of the signals, conformational analysis by DFT methods, and single crystal X-ray diffraction, showing a good correlation between the theoretical calculations, the experimental values of energies and the preferred conformations in the solid state. The steric hindering of the crowded substitution at the central amine group was found to be the reason of the presence of permanent atropisomers in this series of compounds, and the cause of a unique disposition of the thioxo group at close-to-right angles with respect to the plane defined by the 1,3-
\end{abstract}


dithiole ring in the dithiafulvene derivatives, thus breaking the sulfur-sulfur hypervalent bond that is always found in this kind of compounds.

\section{INTRODUCTION:}

$3 H$-1,2-Dithiole-3-thione and its derivatives (dithiolethiones) ${ }^{1}$ have been the subject of intense research due to their physiological effects as potent cancer-preventive and anticancer agents, because they are inducers of cytoprotective phase 2 enzymes, ${ }^{2}$ and are currently used as hepatoprotective agents in clinical trials. ${ }^{3}$ Most recently they have been studied as hydrogen sulfide-releasing drugs with high therapeutic potential in the $\mathrm{H}_{2} \mathrm{~S}$ signaling system for relevant research areas such as cardiovascular and gastrointestinal systems, immunology and cancer biology, ${ }^{4}$ and in the control of oxidative posttranslational cysteine modifications with medical applications. ${ }^{5}$ Instead the 1,3-dithiol-2-ylidene derivatives (dithiafulvenes) ${ }^{6}$ are important donor units in electronic materials and molecular devices such as organic superconductors, ${ }^{7}$ push-pull chromophores, ${ }^{8}$ switchable organic materials, ${ }^{9}$ and receptors. ${ }^{10}$ Apart from classical methods ${ }^{11}$ for the preparation of 1,3-dithiole derivatives, the 1,3-dipolar cycloadditions of 1,2-dithiole-3-thiones and activated triple bonds permits multiple cycloadditions in one pot, therefore giving rise to complex derivatives by very short reaction pathways. ${ }^{12}$ With the aim to prepare new derivatives for anticancer screening schemes, ${ }^{13}$ we revisited an old reaction that was useful for that purpose. As in the previous case, some starting materials and some reaction products obtained from the reported sequence showed an intriguing dynamical behavior by either ${ }^{1} \mathrm{H}$ or ${ }^{13} \mathrm{C}$ NMR that, despite the increasing complexity, could be studied by a combination of experimental and computational methods. Dynamic NMR studies are common tools for the elucidation of inversion-rotation barriers in stereodynamics of hindered heterocyclic systems, ${ }^{14}$ rotation barriers in orthodisubstituted biaryls ${ }^{15}$ and molecular rotors. $^{16}$ Studies involving polysulfur heterocyclic 
compounds are much more scarce, ${ }^{17}$ therefore new findings in this field are of great interest. In this paper we now report the synthesis and the dynamic NMR study of some new 1,4-dithiafulvene 2$(N, N$-dialkylamino)thioacetanilides and their starting materials, supported by DFT calculations and X-ray diffraction analysis of structures of key compounds.

\section{RESULTS AND DISCUSSION:}

The synthesis of the new compounds $\mathbf{6 a - d}$ was accomplished in two steps from amines 1a-b by the selective sulfuration of a tertiary isopropylamine group. ${ }^{6,12 a, 13}$ The mechanism of the transformation of $\mathbf{1 a - b}$ to $\mathbf{2 a - b}$ is complicated and involve several steps explained in earlier publications. ${ }^{18}$ This process was performed by the reaction of $\mathrm{S}_{2} \mathrm{Cl}_{2}$ (5 equiv) with $N$-(2phthalimidoethyl)- $N$-alkylisopropylamines [alkyl = isopropyl, 2,2-dimethylpropyl (neopentyl)] 1ab ( 1 equiv) in the presence of $\mathrm{DABCO}$ (4 equiv) in $\mathrm{CHCl}_{3}$ at room temperature for 3 days, followed by reaction of the mixture with triethylamine ( 6.5 equiv) for additional two hours at room temperature, all in a one-pot process. Reaction work-up and column chromatography of the residue gave 2a $(45 \%)$ or $\mathbf{2 b}(30 \%)$. Cycloaddition of $\mathbf{2 a - b}$ with dimethyl or diethyl acetylenedicarboxylate (3a-b, 1 equiv) quantitatively afforded the thioacid chlorides $\mathbf{4 a - d}$ as red solids, which were sufficiently stable to be characterized by spectroscopy. Thioacid chlorides $\mathbf{4 a - d}$ reacted with one equivalent of aniline $\mathbf{5 a}$ or 2 -( $N, N$-dimethylamino)ethylmercaptane $\mathbf{5 b}$ to give products 6a-d (54-89\%). Isolation of 4a-d was not necessary for the preparation of products 6a-d which, in fact, were obtained in one-pot reactions from $\mathbf{2} \mathbf{a}-\mathbf{b}$ by the sequential addition of reagents at room temperature (Scheme 1). The obtained compounds were fully characterized by spectroscopy and gave satisfactory microanalyses (see Experimental Section and Supporting Information). 
Scheme 1. New (1,3-dithiol-2-ylidene)ethanethioamides and dithioesters
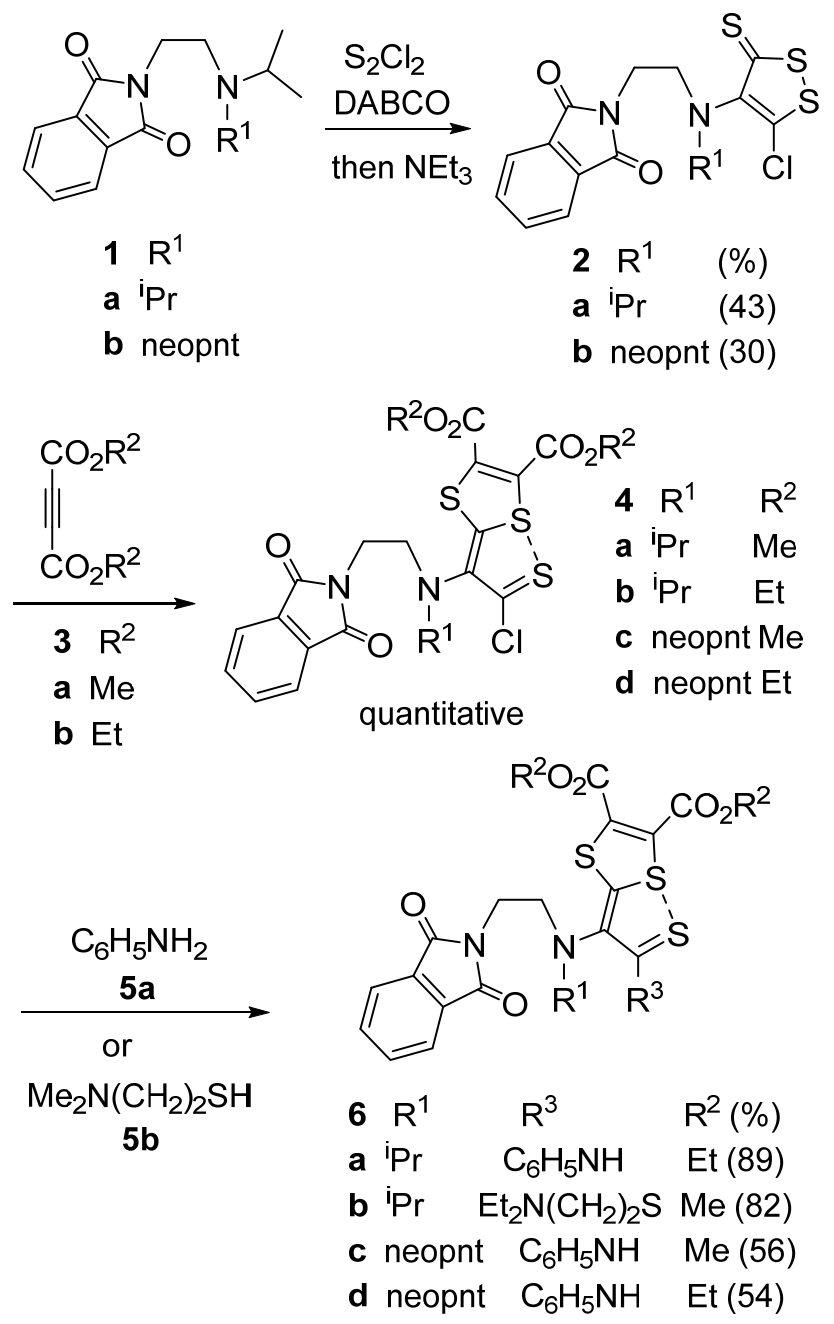

From the large collection of compounds that could be obtained by this series of reactions, the selected compounds 6a-d were ideally suited for the study of their dynamic NMR behavior as new molecular atropisomeric probes because all of them showed diastereomeric preferred conformations, studied by dynamic NMR, of the isopropyl or neopentyl signals. In this way, compounds 6a-b showed diastereomeric preferred conformations of the isopropyl signals in dynamic NMR. The ${ }^{1} \mathrm{H}$ NMR spectrum of 6 a showed a broad signal at $\delta 1.1$ in deuterated chloroform at room temperature, corresponding to slowly interchanging methyl groups of the 
isopropyl group. The signal was resolved in a doublet of equivalent methyl groups at $80{ }^{\circ} \mathrm{C}$ and in two doublets at $-20^{\circ} \mathrm{C}$. The signals partially superposed to the methyl signals from the ethoxy groups. Instead, the ${ }^{13} \mathrm{C}$ NMR showed a broad pair of signals by $\delta 21$ and 23 at room temperature that was resolved into one signal at $45^{\circ} \mathrm{C}$ and into two neat signals at $-10{ }^{\circ} \mathrm{C}$ (Figure 1). Simulation of the signals with gNMR5.0.4.0 ${ }^{19}$ gave interchange constants $\mathrm{k}\left(\mathrm{s}^{-1}\right)$ that were plotted as $\log \mathrm{k} / \mathrm{T}$ versus $1 / \mathrm{T}$, giving a first order kinetics from which the free energy of transition was calculated to be $\Delta \mathrm{G}^{\ddagger}=14.85 \pm 1.49 \mathrm{kcal} \mathrm{mol}^{-1}$. The same value, $14.85 \mathrm{kcal} \mathrm{mol}^{-1}$, was obtained from the Eyring equation at the coalescence temperature $\mathrm{T}_{\mathrm{c}}=312 \mathrm{~K}$ (Figure 1). Analogously, the ${ }^{1} \mathrm{H}$ NMR spectrum of $\mathbf{6 b}$ showed two broad signals at $\delta 1.1$ and 1.4 in deuterated chlorobenzene at room temperature, corresponding to slowly interchanging methyl groups of the isopropyl group. Its ${ }^{13} \mathrm{C}$ NMR showed a pair of signals at $\delta 20$ and 23 at room temperature that was resolved into one broad signal at $90^{\circ} \mathrm{C}$ (Figure 1). Simulation of the signals with gNMR5.0.4.0 ${ }^{19}$ gave interchange constants $\mathrm{k}\left(\mathrm{s}^{-1}\right)$ that were plotted as $\log \mathrm{k} / \mathrm{T}$ versus $1 / \mathrm{T}$, giving a first order kinetics from which the free energy of transition was calculated to be $\Delta \mathrm{G}^{\ddagger}=16.45 \pm 0.12 \mathrm{kcal} \mathrm{mol}^{-1}$. A similar value, 16.42 $\mathrm{kcal} \mathrm{mol}{ }^{-1}$, was obtained from the Eyring equation at the coalescence temperature $\mathrm{T}_{\mathrm{c}}=343 \mathrm{~K}$ (Figure 1). 


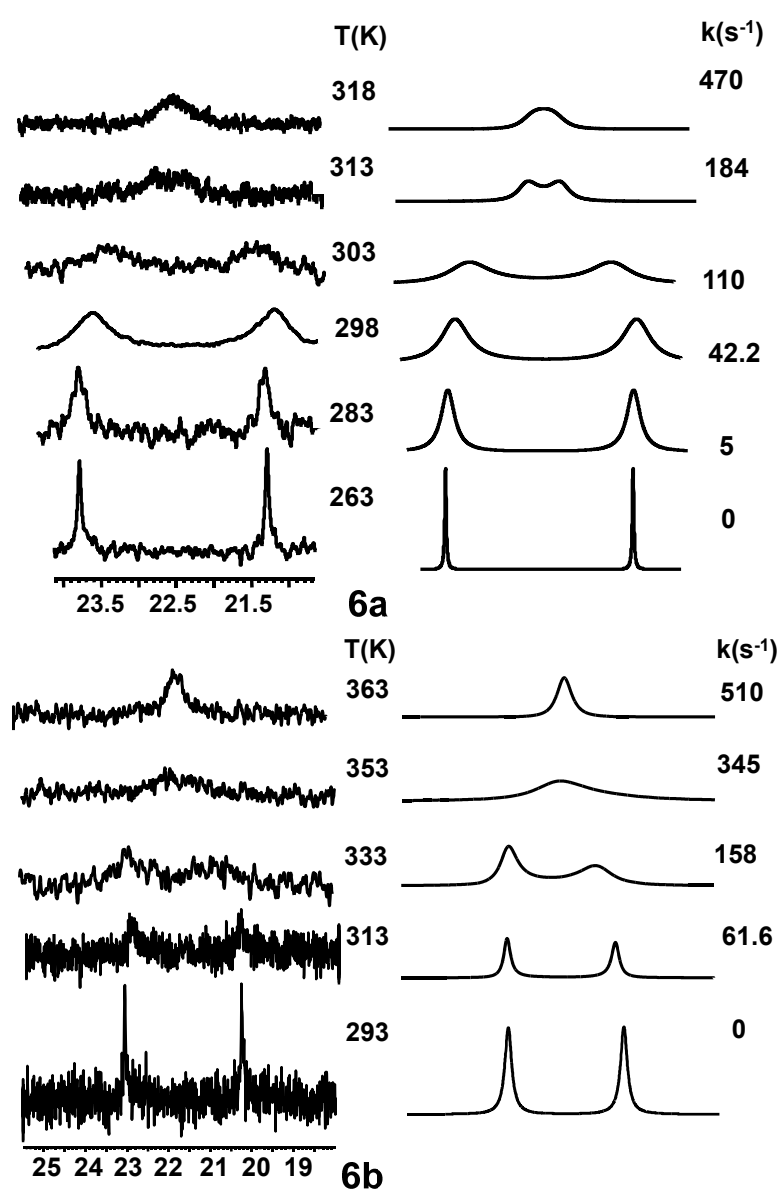

Figure 1. Dynamic ${ }^{13} \mathrm{C}$ NMR signals, simulation of the signals and interchange constants $\mathrm{k}\left(\mathrm{s}^{-1}\right)$ of 6a-b

Compounds 6c-d showed diastereomeric preferred conformations studied by dynamic NMR of the neopenthyl signals. The ${ }^{1} \mathrm{H}$ NMR spectrum of $\mathbf{6 c}$ showed a broad pair of doublets at $\delta 2.8$ and 3.1 in deuterated chlorobenzene at room temperature, corresponding to slowly interchanging methylene protons of the neopentyl group. The signal was resolved in one singlet of equivalent methylene protons at $80{ }^{\circ} \mathrm{C}$ and in two doublets at $-30^{\circ} \mathrm{C}$. Figure 2 shows the dynamic behaviour of the methylene protons of $\mathbf{6 c}$ in ${ }^{1} \mathrm{H}$ NMR (left) and simulation of the signals (right) with gNMR 5.0.4.0. ${ }^{19}$ From these simulations the interchange constants $\mathrm{k}\left(\mathrm{s}^{-1}\right)$ were obtained and plotted 
as $\log \mathrm{k} / \mathrm{T}$ versus $1 / \mathrm{T}$, giving a first order kinetics from which the free energy of transition was calculated to be $\Delta \mathrm{G}^{*}=15.39 \pm 0.99 \mathrm{kcal} \mathrm{mol}^{-1}$. A similar value, $15.48 \mathrm{kcal} \mathrm{mol}^{-1}$, was obtained from the Eyring equation at the coalescence temperature $T_{c}=323 \mathrm{~K}$. Similarly, the ${ }^{1} \mathrm{H}$ NMR spectrum of $\mathbf{6 d}$ showed a pair of doublets at $\delta 2.8$ and 3.1 in deuterated chlorobenzene at room temperature, corresponding to slowly interchanging methylene protons of the neopentyl group, which was resolved in one singlet of equivalent methylene protons at $90{ }^{\circ} \mathrm{C}$. Figure 2 shows the dynamic behaviour of the methylene protons of $\mathbf{6 d}$ in ${ }^{1} \mathrm{H}$ NMR (left) and simulation of the signals (right) with gNMR5.0.4.0. ${ }^{19}$ From these simulations the interchange constants $\mathrm{k}\left(\mathrm{s}^{-1}\right)$ were obtained and plotted as $\log \mathrm{k} / \mathrm{T}$ versus $1 / \mathrm{T}$, giving a first order kinetics from which the free energy of transition was calculated to be $\Delta \mathrm{G}^{\ddagger}=15.21 \pm 0.66 \mathrm{kcal} \mathrm{mol}^{-1}$. A similar value, $15.18 \mathrm{kcal} \mathrm{mol}^{-1}$, was obtained from the Eyring equation at the coalescence temperature $T_{c}=323 \mathrm{~K}$. In all cases, these values of energy were ascribed to slow inversion-rotation processes that placed the isopropyl or neopentyl groups in diastereotopic environments. 


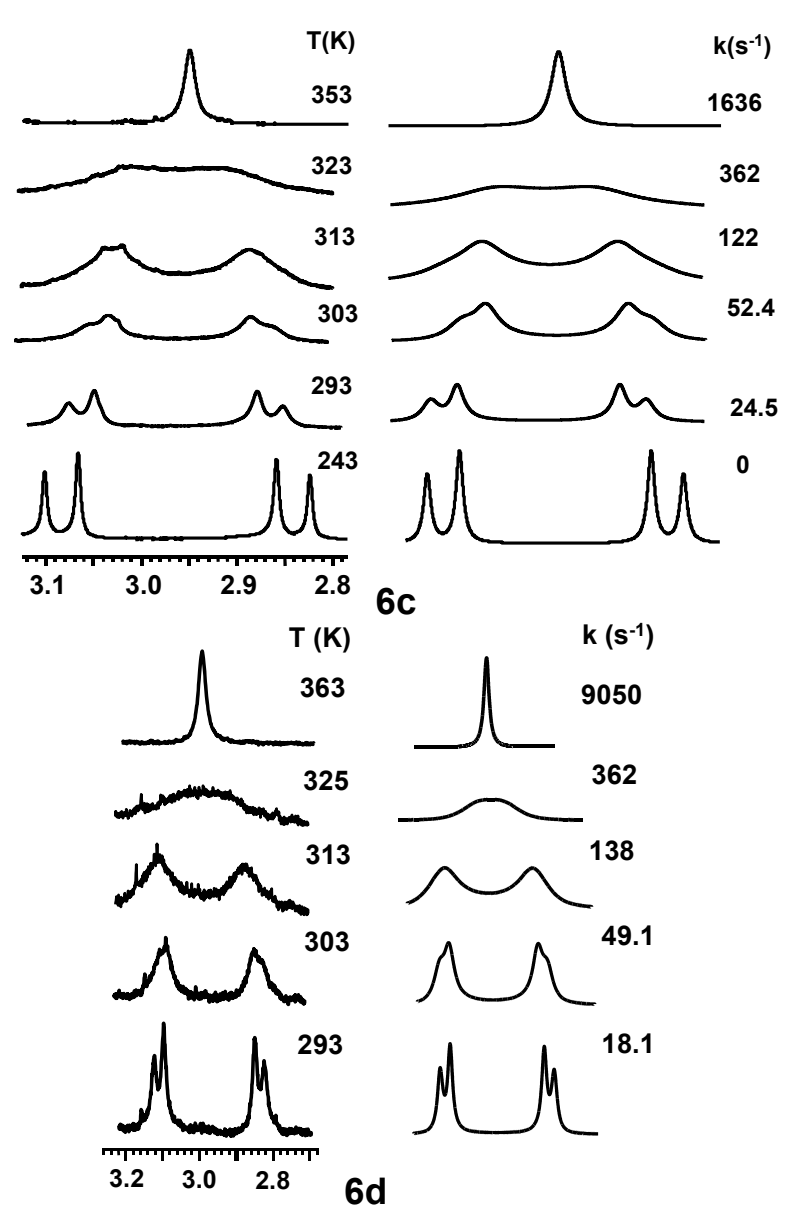

Figure 2. Dynamic ${ }^{1} \mathrm{H}$ NMR signals, simulation of the signals and interchange constants $\mathrm{k}\left(\mathrm{s}^{-1}\right)$ of 6c-d

The dynamic behavior observed for compound 6a has been studied by using DFT methods, as a model for all the series. The observed dynamic behavior in solution could be explained by rotations of the groups bonded to the central amine nitrogen atom such as the isopropyl group. In compound $\mathbf{6 a}$, the observed experimental dynamic process has a barrier of $14.85 \mathrm{kcal} \cdot \mathrm{mol}^{-1}$. In the theoretical study of the rotation of the isopropyl group we have found several stationary points corresponding to five minima and five transition states connecting the minima. The calculated difference of energy between the global minimum and the highest transition state in gas phase is 
$5.13 \mathrm{kcal} \cdot \mathrm{mol}^{-1}$, or $4.00 \mathrm{kcal} \cdot \mathrm{mol}^{-1}$ taking into account solvation effects. This value is far from the $14.85 \mathrm{kcal} \cdot \mathrm{mol}^{-1}$ found experimentally indicating that an alternative dynamic process must be occurring simultaneously. The theoretical study of the rotation of the thiocarboxamide fragment affords four minima along with four transition states between them (Figure 3). In this second process the biggest difference in energy between the global minimum and the highest transition state in gas phase is $13.92 \mathrm{kcal} \cdot \mathrm{mol}^{-1}$, which is in good agreement with the experimental value. The free energy value obtained taking into account solvation effects is $12.20 \mathrm{kcal} \cdot \mathrm{mol}^{-1}$, which is in also good agreement with the experimental value. The absolute minimum found in the optimization of the model 6a displays a torsional angle between the axes of the bonds C-S (see Figure 3) of 0 degrees, which is consistent with a planar geometry in the fragment involving these $\mathrm{C}-\mathrm{S}$ bonds. This planar configuration is in good agreement with all the structures found on $\mathrm{CSD}^{20}$ with the same fragment, although in none of them the $\mathrm{C}=\mathrm{S}$ bond was part of a thioamide group. This absolute minimum 6a displays a distance of $1.999 \AA$ between the hydrogen atom of the thioamide group and the amine nitrogen atom. This distance is in the range of the hydrogen bond interactions and it can be classified as a moderate-weak hydrogen bond. ${ }^{21}$ We noticed that in all structures, except rot1 and TS1, the addition of the angles around the amine nitrogen atom is very near to 360 , indicating a flat geometry in this atom. The pyramidalization observed in the rotamer rot 1 can be understood by considering the intramolecular hydrogen bond that appears to be the only reason of the difference with the other rotamers. The flat geometry observed in the other structures could be reasonable considering the big size of the substituents bonded to the nitrogen atom. The angles around the anime nitrogen atom found in the calculated structures of the rotation of the thiocarboxamide fragment in the compound 6a are summarized in page S71 of the Supporting Information. A study of the difference on energies between the ground state, rot1, and the highest transition state in $\mathbf{6 a}$, TS2, when this difference has been calculated at different 
temperatures, has been performed. The calculations show that there is not a big change when the temperature rises from $263 \mathrm{~K}$ to $318 \mathrm{~K}$. The differences of free energies between rot1 and TS2 with the temperature are shown in pages S71-S72 of the Supporting Information. Calculations were performed in the gas phase at the B3LYP/6-31G(d) level of theory and in solution (PCM, solvent $=$ chloroform $)$ at the B3LYP/6-311G(2d,p) level of theory. Both, gas phase and solvatation calculations are in good agreement with the experimental results. Although the observed trend is correct, the calculations taking into account solvatation effects with a polarizable continuum model (PCM) yielded a slight deviation from the experimental values (about $2.6 \mathrm{kcal} / \mathrm{mol}$ ) (See the Supporting Infrmation).

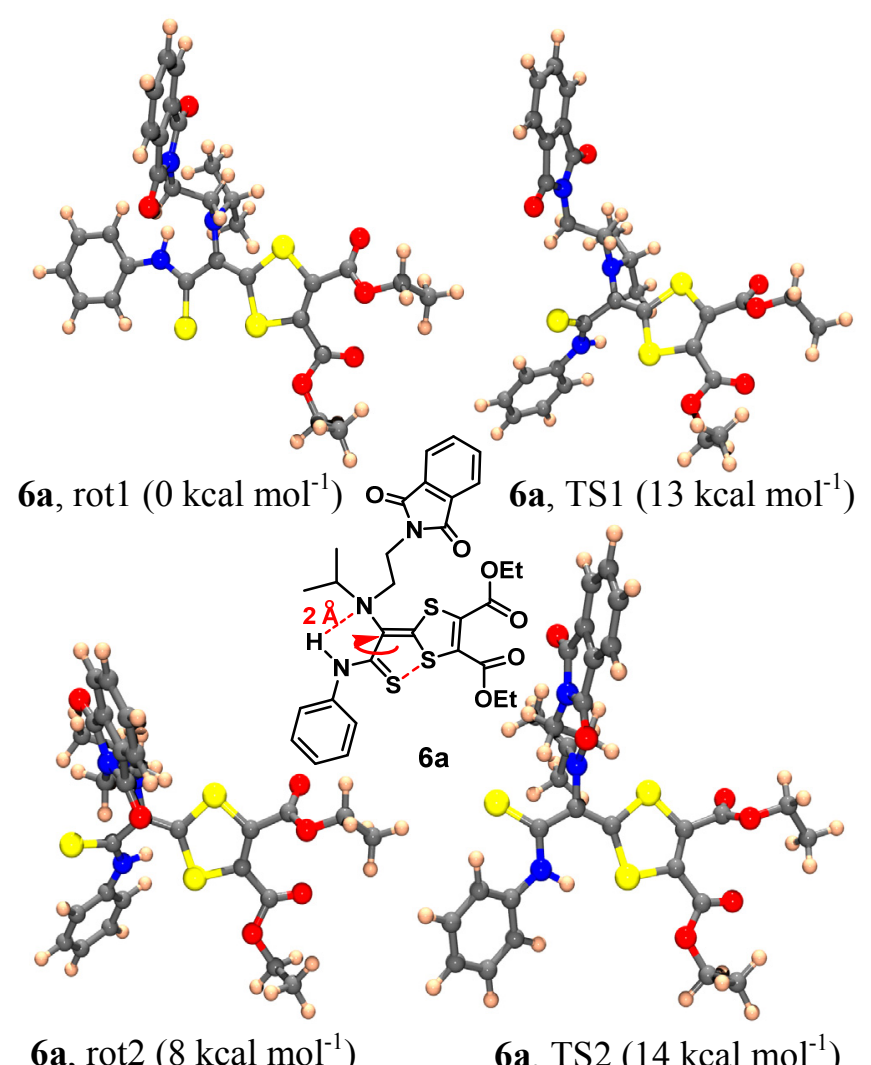

6a, $\operatorname{rot} 2\left(8 \mathrm{kcal} \mathrm{mol}^{-1}\right)$

6a, TS2 $\left(14 \mathrm{kcal} \mathrm{mol}^{-1}\right)$ 
Figure 3. All stationary points found in the process of rotation of the thiocarboxamide fragment in 6a (full information available in the Supporting Information). Inset: Structure 6a showing in red the bond rotated and the S-S hypervalent bonding interaction

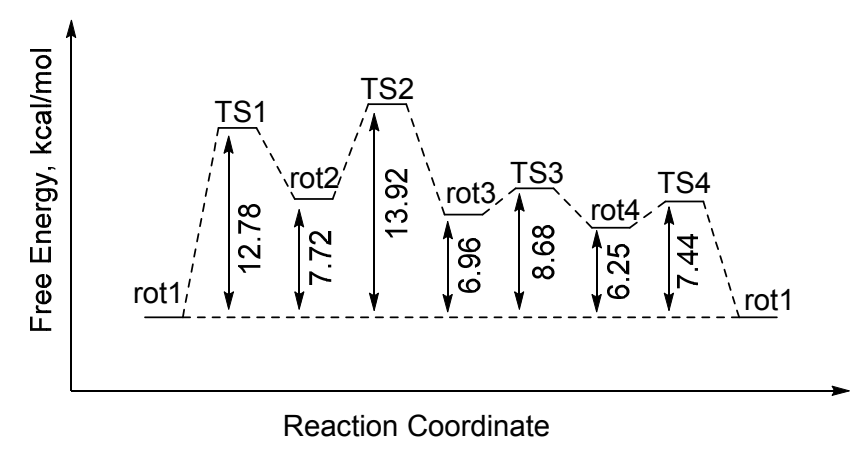

Figure 4. A chart of energies for the four minima and the four transition states of the rotation of the thiocarboxamide fragment in $\mathbf{6 a}$ 
An additional rotation can be proposed in which the rotation should involve the N-C bond connecting the amine nitrogen with the carbon atom that links the thiocarbamide and dithiafulvene fragments. DFT calculations located two minima in this process, both of them of similar energy (separated only for $1.69 \mathrm{kcal} \cdot \mathrm{mol}^{-1}$ ), being the most stable the previously calculated conformer rot 1 . In both conformers the calculated torsional angle $\mathrm{C}\left({ }^{i} \mathrm{Pr}\right)-\mathrm{N}-\mathrm{C}-\mathrm{C}$ (dithiafulvalene) is $74.84^{\circ}$ and $-67.14^{\circ}$. Two possible transition states connecting these two minima were found. In these two transition states the values for the similar torsional angle were $162.66^{\circ}$ and $41.96^{\circ}$. The optimization of the geometries of these two transition states was performed by restricting the relative orientation of the C-S bonds corresponding to the thiocarboxamide and the dithiafulvalene moieties. The relative orientation was fixed by keeping the same orientation found in rot1. All attempts to find the transition states without this restriction afforded rotation of the $\mathrm{C}-\mathrm{C}$ bond of the thiocarboxamide fragment. Every transition state displayed an imaginary frequency, in good agreement with the rotation of the $\mathrm{N}-\mathrm{C}$ bond, but in both cases the IRC calculations tended to additional rotations of the $\mathrm{C}-\mathrm{C}$ bond of the thiocarboxamide fragment. The minimum calculated free energy for the conversion between the rotamers rot1 and $\operatorname{rot} 1 \mathrm{~b}$ was $28.56 \mathrm{kcal} \cdot \mathrm{mol}^{-1}$ (gas phase), which was almost twice the calculated value for the rotation of the thiocarboxamide fragment and the experimental value found from the dynamic behavior by NMR. Therefore that rotation can't explain the dynamic behavior of $\mathbf{6 a}$, confirming rotation of the thiocarboxamide fragment in $\mathbf{6 a}$ as the most plausible explanation for the experimental results. 


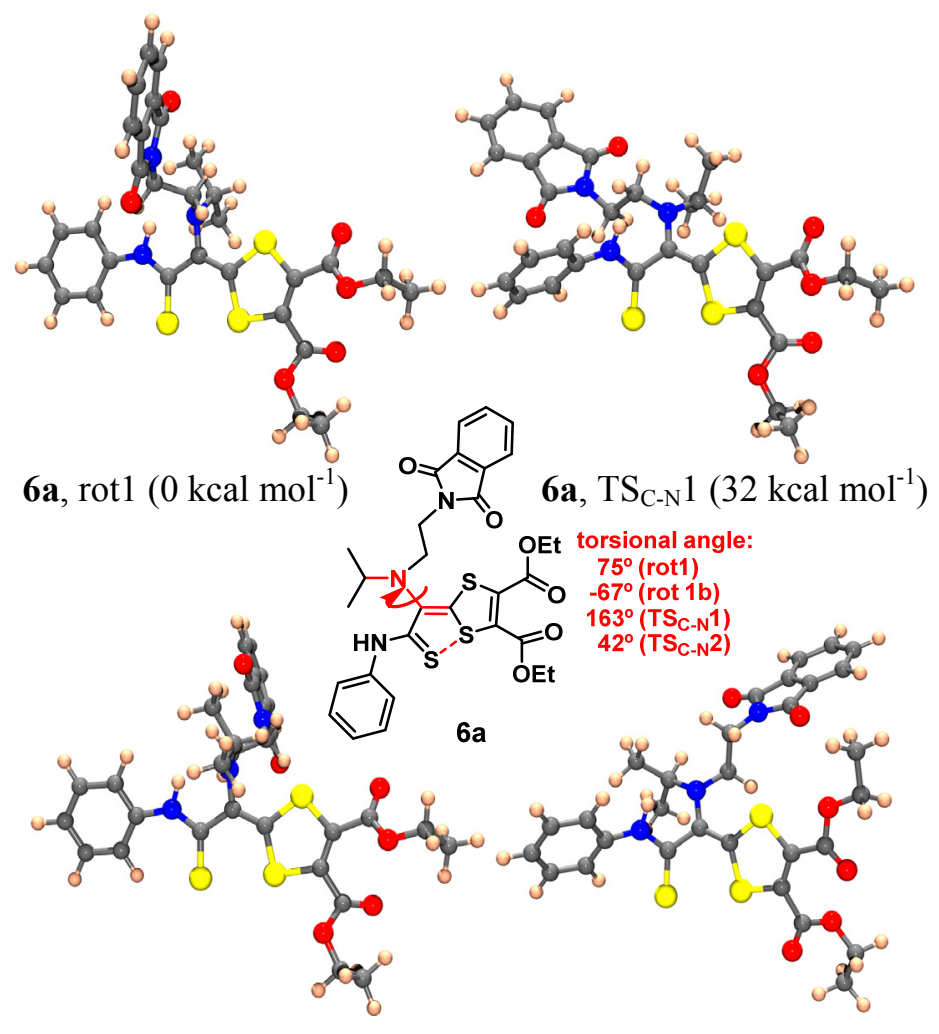

6a, $\operatorname{rot} 1 \mathrm{~b}\left(2 \mathrm{kcal} \mathrm{mol}^{-1}\right)$

6a, $\mathrm{TS}_{\mathrm{C}-\mathrm{N}} 2\left(29 \mathrm{kcal} \mathrm{mol}^{-1}\right)$

Figure 5. All stationary points found in the process of rotation of the N-C bond connecting the amine nitrogen with the dithiafulvene carbon in $\mathbf{6 a}$ (full information available in the Supporting Information). Inset: Structure 6a showing in red the bond rotated and the S-S hypervalent bonding interaction

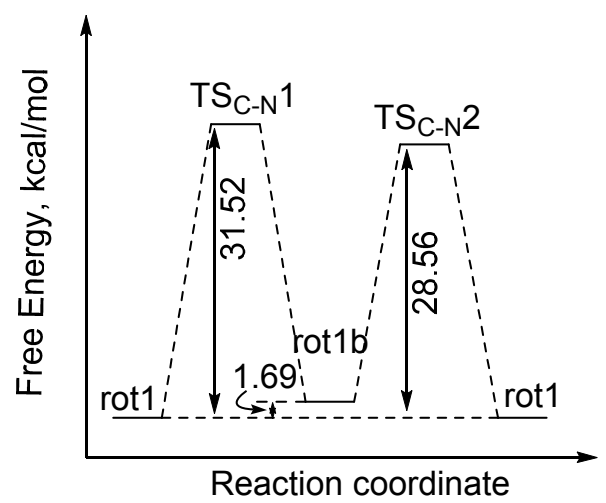


Figure 6. A chart of energies for the two minima and the two transition states of the rotation of the amine fragment in $\mathbf{6 a}$

In order to compare the stereodynamic behavior observed for 6a-d with structural features of similar compounds we tried for several times to crystallize related compounds to $\mathbf{6 a - d}$ that could afford clues about the feasibility of the rotation of the thioamide bond. After several trials we got crystals suitable for X-ray diffraction of a related compound 7 , prepared $^{13}$ by reaction of $\mathbf{4 b}$ and pyrrolidine 5c (Scheme 2). Compound 7 did not showed diastereomeric preferred conformations of the isopropyl signals when studied by dynamic NMR at low temperature so we could only compare experimental results from NMR dynamic behavior and the solid state structure.

Scheme 2. Synthesis of a pyrrolidinyl thioamide derivative 7 for X-ray diffraction.

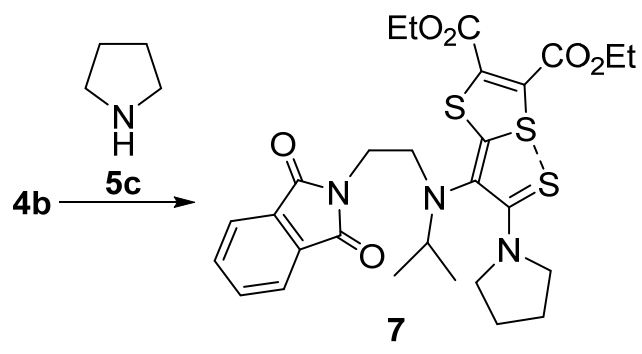

The X-ray diffraction structure of compound 7 showed three different structural conformations of the same molecule in the crystal, showing also molecular disorder in the peripheral ethyl ester groups. Figure 7 shows the three crystallographic independent molecules as they were obtained as part of the same unit cell by single crystal X-ray diffraction structure of compound 7. 


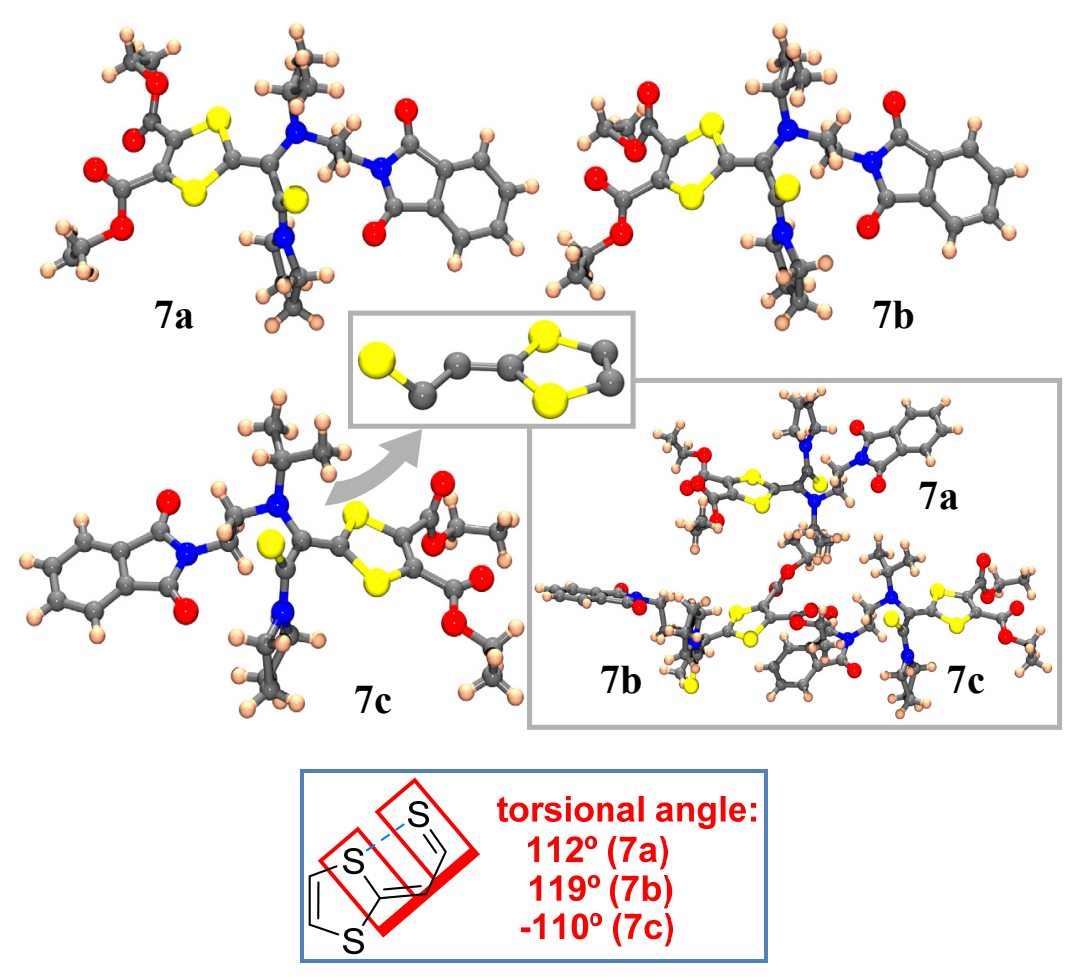

Figure 7. The three crystallographic independent molecules obtained as part of the same unit cell from the single crystal X-ray diffraction structure of 7 and their disposition in the unit cell (red box). Central inset: the 1,3-dithiolanethiocarbonyl group in the closest conformer 7a from the single crystal X-ray diffraction structure. Bottom inset: Torsional angle used as reference S-

$$
\mathrm{C} \cdots \mathrm{C}=\mathrm{S} \text { for structural discussions }
$$

Remarkably, the atomic orientation found in compound 7 is different of the expected for this kind of compounds. The axis of both $\mathrm{C}=\mathrm{S}$ and $\mathrm{C}-\mathrm{S}$ bonds lie in different planes for every one of the three structures of the asymmetric unit. In the three crystallographic independent molecules the torsional angles between the 1,3-dithiole group and the thiocarboxamide group were $111.90(5)^{\circ}$, $119.4(4)^{\circ}$ and $-109.5(5)^{\circ}$. These values of the angles are a consequence of a rotation around the single bond $\mathrm{C}-\mathrm{C}$ contained on the path connecting the $\mathrm{C}=\mathrm{S}$ and $\mathrm{C}-\mathrm{S}$ bonds, as displayed in the inset of Figure 5, for all the conformers of structure 7. This C-C bond in all conformers of structure 7 is 
long, with values ranging between $1.489(7) \AA$ and $1.512(8) \AA$, and these values are only exceeded for one reported compound (1.52(1) $\AA$ and 1.54(1) $\AA)^{22}$ having similar structural fragments as the ones shown in Scheme 2 (inset). The exocyclic double bond $\mathrm{C}=\mathrm{C}$ in compound 7 is the shortest bond found for compounds with this structural fragment, and the $\mathrm{C}=\mathrm{S}$ bond values are in the average of the experimentally observed in CSD. The structure 7 shown in Figure 8 constitutes the first reported example of a solid state structure in which the expected $\mathrm{S} \cdots \mathrm{S}$ hypervalent bonding interaction has been broken. The $\mathrm{S} \cdots \mathrm{S}$ hypervalent bond $^{23}$ lies at the foundations of the polysulfur heterocyclic chemistry. Hypervalent $\mathrm{S} \cdots \mathrm{S} / \mathrm{S} \cdots \mathrm{O} / \mathrm{S} \cdots \mathrm{N}$ interactions are usually important structural features to understand the structure and properties of heterocyclic systems. ${ }^{24}$ Such hypervalent nonbonded $\mathrm{S} \cdots \mathrm{X}$ interactions usually control the molecular structure and chemical reactivity of organic molecules, as well as their assembly and packing in the solid state. ${ }^{25}$ In our case, compounds 6a-d showed a very weak $S \cdots S$ interaction, as seen from the calculations of compound 6a, that allowed the presence of rotamers in all the series of compounds $6 \mathbf{a}-\mathbf{d}$. On the other hand, compound 7 showed no S $\cdots$ S hypervalent interaction in the structure obtained in the solid state. In that case, the structures of the non-planar (starting from the experimental values) and planar models of 7 have been calculated through DFT calculations. From the calculated structures we have found that the non-planar structure (similar to one of the rotamers found in the solid state) is $7.9 \mathrm{kcal} \cdot \mathrm{mol}^{-1}$ more stable than the planar one, which is in good agreement with the structures found in the solid state (Figure 6). 


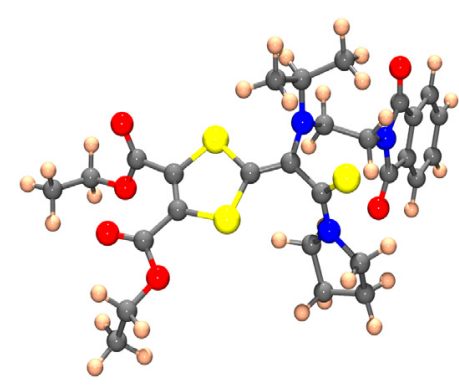

7, $\operatorname{rot} 1\left(0 \mathrm{kcal} \mathrm{mol}^{-1}\right)$

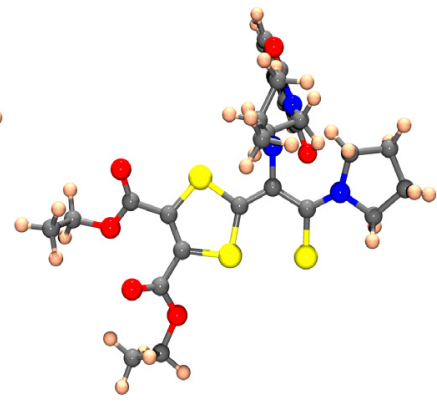

$7, \operatorname{rot} 2\left(8 \mathrm{kcal} \mathrm{mol}^{-1}\right)$

Figure 8. DFT calculated structures of the X-ray diffraction structure 7 and a planar model in which the hypervalent sulfur-sulfur interaction is conserved

In the three experimental structures 7 a-c the nitrogen atom displays a pyramidal geometry. Nevertheless, in the most stable theoretically calculated structure 7, rot1, showing a very similar arrangement for the sulfur atoms of the dithiafulvalene and the thioamide groups, the amine nitrogen atom displays an almost planar geometry. As in the case of compound 6a, this flat geometry can be well understood in terms of steric hindrance of the substituents bonded to the nitrogen atom for the calculated geometry of the isolated molecule (gas phase). The pyramidal geometry found in the experimental structure could be due to packing interactions in the solid state that are not present in the gas phase. The values of the angles surrounding the amine nitrogen atom along with the same values found in the two theoretically calculated rotamers for compound 7 are displayed in page S107 of the Supporting Information. Therefore, for compounds $6 \mathbf{6}$ and 7 the big steric hindrance of the substituents of the amine nitrogen favors the planar geometry of the amine. Nevertheless, the pyramidal geometry has to be very easily accessible (low energy process) with the help of an intramolecular hydrogen bond (6a) or packing reticular interactions (7). This low energy process does not affect to the overall energy of the hypervalent sulfur-sulfur interaction. The only structural difference between $\mathbf{6 a - d}$ and $\mathbf{7}$ is the presence of a more rigid tertiary thioamide in $\mathbf{7}$ and a more flexible thioanilide or dithioester in $\mathbf{6 a - d}$. The thioanilide group favors 
the presence of a hydrogen bond between the hydrogen atom of the thioamide and the amine nitrogen atom, which contributes to the stability of the S-S bonding interaction. The absence of an $\mathrm{N}-\mathrm{H}$ amide hydrogen in compound 7 avoids this hydrogen interaction. Although no related thioamides were found at the CSD database, all found (1,3-dithiol-2ylidene)ethanethiocarbonyl, ${ }^{12 \mathrm{~d}, 26}$ carbonyl, ${ }^{27}$ or imine derivatives ${ }^{28}$ were always planar, despite a high steric hindering of the groups. ${ }^{27 g-i}$ Therefore a combination of steric hindering of the crowded substitution at the central amine group, as well as electronic effects from the push-pull electronic delocalization, in addition of the conjugation due to the thioamide group and the presence of a hydrogen bond, seem to be the cause of the weak or absent $\mathrm{S} \cdots \mathrm{S}$ hypervalent interaction. Such structural motif can be of interest for pharmacological as well as materials design, therefore a closer inspection of the electronic structure by using the Natural Bond Orbital population approach (NBO) analyses for the models 6a_rot1 and 7_rot2 (the most stable conformer of 6a and planar conformer of 7 respectively) were performed for the evaluation of the electronic delocalization. For conformer 6a_rot1, these calculations clearly indicated the presence of two lone pair orbitals formally attached at the thiocarboxylic sulfur atom and to the dithiafulvene sulfur atoms. The nature of one of these orbitals on each sulfur atom is a pure $p$-type $\left[\operatorname{lp}_{\mathrm{p}}(\mathrm{S})\right]$, having the orbitals of the sulfur atoms of the dithiafulvene a low electron occupancy of 1.65 and $1.68 \mathrm{e}$, indicating the electron-donating capacity for this orbital. Delocalizing interactions evaluated by a second-order perturbation approach revealed that the lone pair orbital located at the dithiafulvene sulfur atoms contributed to a resonance interaction with double bond $\mathrm{C}(32)=\mathrm{C}(33)$ (see scheme 3 for numbering) $\operatorname{lp}_{\mathrm{p}}(\mathrm{S}) \rightarrow \pi^{*}(\mathrm{C}-\mathrm{C})$. The computed $\mathrm{E}^{(2)}$ interaction value was 26.1 and $23.3 \mathrm{kcal} / \mathrm{mol}$ for sulfur atoms $\mathrm{S}(34)$ and $\mathrm{S}(35)$ respectively. Interestingly, in the analysis of more delocalizing interactions it was possible to find a second delocalization of pair of electrons located at the bonding orbital $\pi(C-C)$ involving atoms $C(32)$ and $C(33)$ with the double bond $C(38)=S(39)$, 
Scheme 3. Labeling of the atoms used for the NBO analyses for the models 6 a $\_$rot1 and 7 rot2
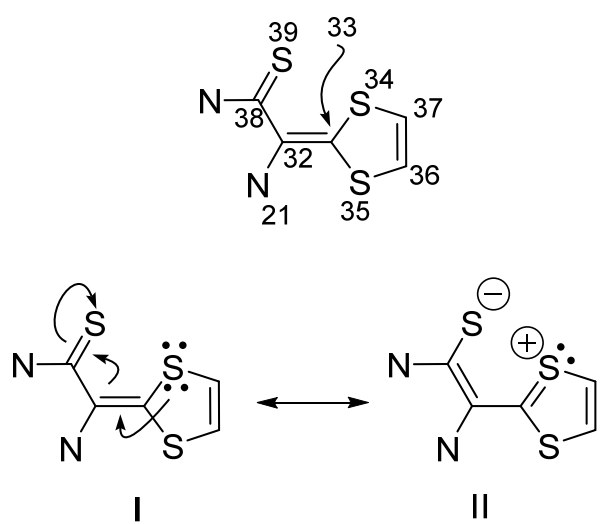

To validate the suitability of our DFT calculations, we applied the same methodology to the dynamic behaviour of previously studied compound 2a, whose dynamic behavior was already studied using a semiempirical level of theory, ${ }^{13}$ and the similar compound $\mathbf{2 b}$ by the same type of calculations using DFT methods. As we previously noticed, the observed dynamic behavior for $\mathbf{2 a}$ in solution could be explained by a rotation around the $\mathrm{C}-\mathrm{N}$ bond connecting the amine nitrogen atom with the 1,2-dithiol group. In this rotation we have now found several stationary points 
corresponding to four minima and four transition states connecting them (see Supporting Information). The calculated difference of energy between the global minimum and the highest transition state was $14.5 \mathrm{kcal} \mathrm{mol}^{-1}$, which was in good agreement with the experimentally calculated value. We also checked the accuracy of our DFT calculations by comparing the minimum obtained for $\mathbf{2 a}$ and the single crystal X-ray diffraction structure obtained for $\mathbf{2 a}$. Indeed, in both cases the structures were practically superimposable. A similar study developed for compound $\mathbf{2 b}$ afforded close related results, but in this case the higher steric hindrance of the neopentyl fragment hampered a simple explanation of the dynamic behavior observed. For this compound three different dynamic processes have been calculated and all of them are rotations around the three $\mathrm{C}-\mathrm{N}$ bonds of the amine nitrogen atom. For the rotation around the $\mathrm{C}-\mathrm{N}$ bond connecting the amine nitrogen atom with the 1,2-dithiol group only one transition state was localized. This transition state connected two rotamers arising from the rotation of the dithiole heterocycle. The energy of the barrier found for this rotation was $11.77 \mathrm{kcal} \cdot \mathrm{mol}^{-1}$. This value was no so far from the experimental value for the dynamic behavior observed on this compound (14.52 $\mathrm{kcal} \cdot \mathrm{mol}^{-1}$ ) (Supporting Information, page 4), but it was not so precise, indicating that other dynamic behavior can be occuring simultaneously. This other dynamic behavior could be the rotation of the neopentyl fragment or the phthalimidoethyl fragment or both. The energy of the barriers theoretically calculated for these processes were $6.54 \mathrm{kcal} \cdot \mathrm{mol}^{-1}$ and $5.14 \mathrm{kcal} \cdot \mathrm{mol}^{-1}$ respectivelly. A simultaneous combination of two of these rotations could account for a closer value to the experimentally calculated one (See Supporting Information).

\section{CONCLUSIONS:}

In conclusion, new atropisomers of (1,3-dithiol-2-ylidene)ethanethioamides and a dithioester have been studied by a combination of dynamic NMR, simulation of the signals, conformational 
analysis by DFT methods, and single crystal X-ray diffraction of one crystalline example, showing a good correlation between the theoretical calculations, the experimental values of energies and the preferred conformations in the solid state. The steric hindering of the crowded substitution at the central amine group, in addition of push-pull electronic delocalization due to the presence of the thioamide or thioester group, was found to be the reason of the presence of permanent atropisomers in this series of compounds, and the cause of a unique disposition of the thioxo group at close-to-right angles with respect to the plane defined by the 1,3-dithiole ring in the dithiafulvene derivatives, thus breaking the sulfur-sulfur hypervalent bonding interaction responsible for the planarity of this kind of heterocyclic systems. Because the hypervalent nonbonded $\mathrm{S} \cdots \mathrm{S}$ interactions usually control the molecular structure and chemical reactivity of organic molecules, as well as their assembly and packing in the solid state, we think that such new structural motif can be of interest for pharmacological as well as materials design.

\section{EXPERIMENTAL SECTION:}

General: The reactions were conducted under dry nitrogen. The solvents were previously distilled under nitrogen over phosphorous pentoxide, calcium hydride or sodium filaments. Melting points were not corrected. Infrared spectra were registered in potassium bromide tablets. NMR spectra were recorded in DMSO- $d_{6}, \mathrm{CDCl}_{3}, \mathrm{CD}_{3} \mathrm{CN}$, and $\mathrm{CD}_{3} \mathrm{OD}$. Chemical shifts are reported in ppm with respect to residual solvent protons, ${ }^{29}$ coupling constants $\left(J_{\mathrm{X}-\mathrm{X}},\right)$ are reported in Hz. DEPT experiments from selected samples permitted assignation of ${ }^{13} \mathrm{C}$ NMR chemical shifts. Elemental analyses of $\mathrm{C}, \mathrm{H}$ and $\mathrm{N}$ were taken for all new products. High resolution mass spectra were taken in a quadrupole mass spectrometer machine by electronic impact, FAB or LSIMS. Analytical TLC was performed on silica gel 60 plates. Flash column chromatography was carried out on silica gel $(0.040-0.063 \mathrm{~mm})$. 
Quantum Chemical calculations: DFT calculations were performed in this study to determine the optimized geometry, vibrational frequencies, and single-point energy of all stationary points. The hybrid method known as B3LYP, in which the Becke three-parameter exchange functional ${ }^{30}$ and the Lee-Yang-Parr correlation functional was used, ${ }^{31}$ implemented in the Gaussian 03 (Revision C.02) program suite. ${ }^{32}$ The geometry optimization of the stationary points was performed at the B3LYP/6-31G* level of theory. To include solvation effects in our calculations, polarizable continuum model $(\mathrm{PCM})^{33}$ calculation was performed on the single-point energies at the PCM/B3LYP/6-311++G(2d,p). Natural population analysis and second-order Donor $\rightarrow$ Acceptor interaction energies were estimated at the B3LYP/6-311++G(2d,p) level by using the NBO analysis $^{34}$ as implemented in the GAUSSIAN03 program.

Crystal Structure Determination for Compounds 2a and 7. A suitable crystal was mounted on a glass fibre. X-ray measurements were made using a CCD area-detector diffractometer with Mo$\mathrm{K}_{\alpha}$ radiation $(\lambda=0.71073 \AA) .{ }^{35}$ Intensities were integrated ${ }^{36}$ from several series of exposures, each exposure covering $0.3^{\circ}$ in $\omega$, and the total data set being a sphere. Absorption corrections were applied, based on multiple and symmetry-equivalent measurements. ${ }^{37}$ The structure was solved by direct methods and refined by least squares on weighted $\mathrm{F}^{2}$ values for all reflections. ${ }^{38}$ All non-hydrogen atoms were assigned anisotropic displacement parameters and refined without positional constraints, except for compound 7 in which all fragments $\mathrm{C}-\mathrm{O}-\mathrm{CH}_{2}-\mathrm{CH}_{3}$ were refined with positional restraints. All hydrogen atoms were constrained to ideal geometries and refined with fixed isotropic displacement parameters. Complex neutral-atom scattering factors were used. $^{39}$

Synthesis of 5-chloro-1,2-dithiole-3-thiones. $N$-[(2-diisopropylamino)ethyl]phthalimide 1 a and $N$-[2-( $N^{\prime}$-isopropyl- $N^{\prime}$-2,2-dimethylpropylamino)ethyl]phthalimide $\mathbf{1 b}$ were prepared as 
described. ${ }^{13}$ Disulfur dichloride $(10 \mathrm{mmol})$ was added dropwise at $-40^{\circ} \mathrm{C}$ to a stirred solution of isopropylamine 1a-b (0.55 g 1a, $0.60 \mathrm{~g} \mathrm{1b}, 2 \mathrm{mmol})$ and DABCO $(0.90 \mathrm{~g}, 8 \mathrm{mmol})$ dissolved in anhydrous chloroform $(50 \mathrm{~mL})$ under nitrogen. The mixture was stirred at $-40^{\circ} \mathrm{C}$ for $15 \mathrm{~min}$ and at room temperature for 3 days, then triethylamine $(1.32 \mathrm{~g}, 13 \mathrm{mmol})$ was added at $-20^{\circ} \mathrm{C}$ and the mixture stirred for additional 2 hours at room temperature. Then the mixture was filtered over celite and the solvent was evaporated under reduced pressure. The resulting solid was purified by MPLC (silica C60 Merck, light petroleum, and then light petroleum- $\mathrm{CH}_{2} \mathrm{Cl}_{2}$ 1:1) to give the corresponding product.

4-[N-(2-Phthalimidoethyl)- $N$-isopropyl]amino-5-chloro-1,2-dithiole-3-thione $\quad \mathbf{2 a} .^{13} \quad 0.34 \mathrm{~g}$, $43 \%$, dark yellow crystals (light petroleum- $\mathrm{CH}_{2} \mathrm{Cl}_{2}$ ), mp $153-154^{\circ} \mathrm{C} ;{ }^{1} \mathrm{H}$ NMR $\left(400 \mathrm{MHz}, \mathrm{CDCl}_{3}\right)$ $\delta$ 1.00-1.40 (m, 6H); 3.47-3.87 (m, 5H); 7.66-7.83 (m, 4H, $\left.\mathrm{H}_{\mathrm{Ar}}\right) ;{ }^{13} \mathrm{C} \mathrm{NMR}\left(100 \mathrm{MHz}, \mathrm{CDCl}_{3}\right.$, DEPT) $\delta 22.2\left(2 \times \mathrm{CH}_{3}\right), 37.8\left(\mathrm{CH}_{2}\right), 42.8\left(\mathrm{CH}_{2}\right), 53.2(\mathrm{CH}), 123.0\left(\mathrm{CH}_{\mathrm{Ar}}\right), 132.0(\mathrm{Cq}), 133.8$ $\left(\mathrm{CH}_{\mathrm{Ar}}\right), 150.2(\mathrm{Cq}), 158.0(\mathrm{Cq}), 168.1(2 \times \mathrm{C}=\mathrm{O}), 209.3(\mathrm{C}=\mathrm{S}) ; \mathrm{IR}(\mathrm{KBr}) \tilde{v}$ 3450, 2968, 1700 $(\mathrm{C}=\mathrm{O}), 1397,1290(\mathrm{C}=\mathrm{S}), 1028,723 \mathrm{~cm}^{-1}$; EIMS m/z $398\left(\mathrm{M}^{+}, 6\right), 222(90), 180$ (100), 174 (65), 49 (70); HRMS (EI) calcd for $\mathrm{C}_{16} \mathrm{H}_{15} \mathrm{ClN}_{2} \mathrm{O}_{2} \mathrm{~S}_{3}$ : 397.9984; found 397.9977; Anal. Calcd for $\mathrm{C}_{16} \mathrm{H}_{15} \mathrm{ClN}_{2} \mathrm{O}_{2} \mathrm{~S}_{3}: \mathrm{C}, 48.17 ; \mathrm{H}, 3.79 ; \mathrm{N}, 7.02$. Found: C, 48.17; H, 3.69; N, 6.95. Crystal data for 2a, $\mathrm{C}_{16} \mathrm{H}_{15} \mathrm{ClN}_{2} \mathrm{O}_{2} \mathrm{~S}_{3}, M=398.93$, triclinic, $\mathrm{P}-1, a=7.900(3) \AA, b=11.409$ (4) $\AA, c=11.512(4) \AA$, $\alpha=63.212(5)^{\mathrm{o}}, \beta=86.744(6)^{\mathrm{o}}, \gamma=79.229(6)^{\mathrm{o}} ; V=909.4(6) \AA^{3}, Z=2, D_{\text {calc }}=1.457 \mathrm{gcm}^{-1}, \mu(\mathrm{Mo}-$ $\left.\mathrm{K}_{\alpha}\right)=0.566 \mathrm{~mm}^{-1}$. Yellow needle, $(0.40 \times 0.30 \times 0.10) \mathrm{mm}^{3} .7535$ measured reflections, 3098 independent $\left(\mathrm{R}_{\mathrm{int}}=0.0154\right), 2721$ observed $(I>2 \sigma(I)) . R_{1}=0.0372, \mathrm{w} R_{2}=0.1082$ (all data), CCDC 1010581.

4-[N-(2-Phthalimidoethyl)- $N$-(2,2-dimethylpropyl)]amino-5-chloro-1,2-dithiole-3-thione 2 b. ${ }^{13}$ $0.26 \mathrm{~g}, 30 \%$, orange solid (light petroleum- $\left.\mathrm{CH}_{2} \mathrm{Cl}_{2}\right)$, mp $135-136{ }^{\circ} \mathrm{C} ;{ }^{1} \mathrm{H} \mathrm{NMR}\left(400 \mathrm{MHz}, \mathrm{CDCl}_{3}\right) \delta$ $0.87(\mathrm{~s}, 9 \mathrm{H}), 2.94-3.03(\mathrm{~m}, 1 \mathrm{H}), 3.33-3.78(\mathrm{~m}, 5 \mathrm{H}), 7.66-7.88\left(\mathrm{~m}, 4 \mathrm{H}, \mathrm{H}_{\mathrm{Ar}}\right) ;{ }^{13} \mathrm{C} \mathrm{NMR}(100 \mathrm{MHz}$, 
$\left.\mathrm{CDCl}_{3}\right) \delta 27.6,34.6,36.5,52.3,62.6,123.1,132.0,133.9,150.9,155.5,168.1,208.4 ; \mathrm{IR}(\mathrm{KBr}) \tilde{v}$ 1772, $1709(\mathrm{C}=\mathrm{O}), 1466,1433,1395,1364 \mathrm{~cm}^{-1}(\mathrm{C}=\mathrm{S})$; EIMS m/z $426\left(\mathrm{M}^{+}, 21\right), 369(100), 266$ (35), 174 (79); HRMS (EI) calcd for $\mathrm{C}_{18} \mathrm{H}_{19} \mathrm{ClN}_{2} \mathrm{O}_{2} \mathrm{~S}_{3}$ : 426.0297; found 426.0308; Anal. Calcd for: $\mathrm{C}_{18} \mathrm{H}_{19} \mathrm{ClN}_{2} \mathrm{O}_{2} \mathrm{~S}_{3}$ : C, 50.63; H, 4.48; N, 6.56. Found: C, 50.58; H, 4.36; N, 6.43.

General procedure for the synthesis of thioacid chlorides 4a-d. Dimethyl or diethyl acetylenedicarboxylate 3a-b (36 mg 3a, $43 \mathrm{mg} \mathbf{3 b}, 0.25 \mathrm{mmol}$ ) was added to a solution of 1,2dithiole-3-thione 2a-b (100 mg 2a, $107 \mathrm{mg} \mathrm{2b}, 0.25 \mathrm{mmol})$ in dry benzene ( $5 \mathrm{~mL})$ under nitrogen and the mixture was refluxed for 1.5 hours, then the solvent was evaporated under reduced pressure to yield the corresponding thioacyl chloride.

Dimethyl 6-[N-(2-phthalimidoethyl)- $N$-isopropyl]amino-6-chlorothiocarbonyl-1,4dithiafulvene-2,3-dicarboxylate $4 \mathbf{a}^{13} 134 \mathrm{mg}, 99 \%$, red sticky solid (benzene); ${ }^{1} \mathrm{H}$ NMR (200 $\left.\mathrm{MHz}, \mathrm{C}_{6} \mathrm{D}_{5} \mathrm{Cl}\right) \delta 1.09(\mathrm{~d}, J=6.3,3 \mathrm{H}), 1.45(\mathrm{~d}, J=6.3,3 \mathrm{H}), 3.57-3.76(\mathrm{~m}, 9 \mathrm{H}), 3.98-4.02(\mathrm{~m}, 2 \mathrm{H})$, 7.43-7.48 (m, 2H, $\left.\mathrm{H}_{\mathrm{Ar}}\right), 7.71-7.74\left(\mathrm{~m}, 2 \mathrm{H}, \mathrm{H}_{\mathrm{Ar}}\right) ;{ }^{13} \mathrm{C} \mathrm{NMR}\left(50 \mathrm{MHz}, \mathrm{CDCl}_{3}\right) \delta 20.1,23.4,38.5$, $51.4,53.3,53.4,55.0,123.2,132.5,133.8,134.4,135.5,137.9,159.7,159.9,167.8,174.6,182.4$; IR (KBr) $\tilde{v} 3472,2967,1710(\mathrm{C}=\mathrm{O}), 1568,1252 \mathrm{~cm}^{-1}(\mathrm{C}=\mathrm{S})$; EIMS m/z $540\left(\mathrm{M}^{+}, 9\right), 505$ (39); HRMS (EI) calcd for $\mathrm{C}_{22} \mathrm{H}_{21} \mathrm{ClN}_{2} \mathrm{O}_{6} \mathrm{~S}_{3}$ : 540.0250; found 540.0261.

Diethyl 6-[N-(2-phthalimidoethyl)- $N$-isopropyl]amino-6-chlorothiocarbonyl-1,4dithiafulvene-2,3-dicarboxylate $4 \mathbf{b} .{ }^{13} 140 \mathrm{mg}, 98 \%$, red solid (benzene), mp 80-82 $\mathrm{C}$; ${ }^{1} \mathrm{H}$ NMR $\left(200 \mathrm{MHz}, \mathrm{CDCl}_{3}\right) \delta 1.01(\mathrm{~d}, J=6.2,3 \mathrm{H}), 1.23-1.57(\mathrm{~m}, 9 \mathrm{H}), 3.31-3.50(\mathrm{~m}, 2 \mathrm{H}), 3.56(\mathrm{hept}, J=$ 6.2, 1H), 3.70-3.96 (m, 2H), 4.18-4.41 (m, 4H), 7.61-7.84 (m, 4H, $\left.\mathrm{H}_{\mathrm{Ar}}\right) ;{ }^{13} \mathrm{C} \mathrm{NMR}(50 \mathrm{MHz}$, $\mathrm{CDCl}_{3}$, DEPT) $\delta 13.4\left(\mathrm{CH}_{3}\right), 13.6\left(\mathrm{CH}_{3}\right), 19.7\left(\mathrm{CH}_{3}\right), 23.0\left(\mathrm{CH}_{3}\right), 38.1\left(\mathrm{CH}_{2}\right), 50.8\left(\mathrm{CH}_{2}\right), 54.6$ $(\mathrm{CH}), 62.6\left(\mathrm{CH}_{2}\right), 62.8\left(\mathrm{CH}_{2}\right), 122.9\left(\mathrm{CH}_{\mathrm{Ar}}\right), 132.4\left(\mathrm{C}_{\mathrm{Ar}}\right), 133.4\left(\mathrm{CH}_{\mathrm{Ar}}\right), 134.9(\mathrm{Cq}), 135.5(\mathrm{Cq})$, $137.5(\mathrm{Cq}), 159.2(\mathrm{Cq}), 159.5(\mathrm{Cq}), 167.5(\mathrm{Cq}), 174.4(\mathrm{Cq}), 182.4(\mathrm{Cq})$; IR (KBr) $\tilde{v} 1715(\mathrm{C}=\mathrm{O})$, 
$1250 \mathrm{~cm}^{-1}(\mathrm{C}=\mathrm{S})$; EIMS $\mathrm{m} / z 568\left(\mathrm{M}^{+}, 10\right), 533(50)$; HRMS (EI) calcd for $\mathrm{C}_{24} \mathrm{H}_{25} \mathrm{ClN}_{2} \mathrm{O}_{6} \mathrm{~S}_{3}$ : 568.0563; found 568.0554.

Dimethyl 6-[N-(2-phthalimidoethyl)-N-(2,2-dimethylpropyl)]amino-6-chlorothiocarbonyl-1,4dithiafulvene-2,3-dicarboxylate $4 c .{ }^{13} 140 \mathrm{mg}, 98 \%$, red sticky solid (benzene); ${ }^{1} \mathrm{H}$ NMR (400 $\left.\mathrm{MHz}, \mathrm{C}_{6} \mathrm{D}_{5} \mathrm{Cl}\right) \delta 0.98(\mathrm{~s}, 9 \mathrm{H}), 2.96(\mathrm{~d}, J=14.5,1 \mathrm{H}), 3.37(\mathrm{~d}, J=14.5,1 \mathrm{H}), 3.28-3.39(\mathrm{~m}, 2 \mathrm{H})$, $3.59(\mathrm{~s}, 3 \mathrm{H}), 3.64(\mathrm{~s}, 3 \mathrm{H}), 3.89-4.08(\mathrm{~m}, 2 \mathrm{H}), 7.30-7.34\left(\mathrm{~m}, 2 \mathrm{H}, \mathrm{H}_{\mathrm{Ar}}\right), 7.61-7.68\left(\mathrm{~m}, 2 \mathrm{H}, \mathrm{H}_{\mathrm{Ar}}\right) ;{ }^{13} \mathrm{C}$ NMR (100 MHz, $\mathrm{CDCl}_{3}$, DEPT) $\delta 28.4\left(3 \mathrm{x} \mathrm{CH}_{3}\right), 33.0(\mathrm{Cq}), 37.6\left(\mathrm{CH}_{2}\right), 53.3\left(\mathrm{CH}_{3}\right), 53.4\left(\mathrm{CH}_{3}\right)$, $55.8\left(\mathrm{CH}_{2}\right), 67.5\left(\mathrm{CH}_{2}\right), 123.4\left(\mathrm{CH}_{\mathrm{Ar}}\right), 127.5\left(\mathrm{CH}_{\mathrm{Ar}}\right), 133.0(\mathrm{Cq}), 134.9\left(\mathrm{CH}_{\mathrm{Ar}}\right), 135.2(\mathrm{Cq}), 140.2$ $(\mathrm{Cq}), 159.6(\mathrm{Cq}), 168.0(\mathrm{Cq}), 170.5(\mathrm{Cq}), 183.0(\mathrm{Cq})$; IR $(\mathrm{KBr}) \tilde{v} 1720(\mathrm{C}=\mathrm{O}), 1245 \mathrm{~cm}^{-1}(\mathrm{C}=\mathrm{S})$; EIMS $m / z 568\left(\mathrm{M}^{+}, 7\right), 533$ (42); HRMS (EI) calcd for $\mathrm{C}_{24} \mathrm{H}_{25} \mathrm{ClN}_{2} \mathrm{O}_{6} \mathrm{~S}_{3}$ : 568.0563; found 568.0569 .

Diethyl 6-[N-(2-phthalimidoethyl)- $N$-(2,2-dimethylpropyl)]amino-6-chlorothiocarbonyl-1,4dithiafulvene-2,3-dicarboxylate 4 d. $^{13} 145 \mathrm{mg}$, 97\% red sticky solid (benzene); ${ }^{1} \mathrm{H}$ NMR (400 $\left.\mathrm{MHz}, \mathrm{CDCl}_{3}\right) \delta 0.97(\mathrm{~s}, 9 \mathrm{H}), 1.27-1.40(\mathrm{~m}, 3 \mathrm{H}), 2.95(\mathrm{~d}, J=14.5,1 \mathrm{H}), 3.12-3.33(\mathrm{~m}, 2 \mathrm{H}), 3.34-$ $3.55(\mathrm{~m}, 1 \mathrm{H}), 3.75-4.01(\mathrm{~m}, 2 \mathrm{H}), 4.22-4.41(\mathrm{~m}, 4 \mathrm{H}), 7.66-7.82\left(\mathrm{~m}, 4 \mathrm{H}, \mathrm{H}_{\mathrm{Ar}}\right) ;{ }^{13} \mathrm{C} \mathrm{NMR}(100 \mathrm{MHz}$, $\left.\mathrm{CDCl}_{3}, \mathrm{DEPT}\right) \delta 13.8\left(\mathrm{CH}_{3}\right), 13.9\left(\mathrm{CH}_{3}\right), 28.4\left(3 \times \mathrm{CH}_{3}\right), 33.1(\mathrm{Cq}), 37.1\left(\mathrm{CH}_{2}\right), 54.3\left(\mathrm{CH}_{2}\right), 63.0$ $\left(\mathrm{CH}_{2}\right), 63.2\left(\mathrm{CH}_{2}\right), 67.2\left(\mathrm{CH}_{2}\right), 123.1\left(\mathrm{CH}_{\mathrm{Ar}}\right), 131.8\left(\mathrm{C}_{\mathrm{Ar}}\right), 133.9\left(\mathrm{CH}_{\mathrm{Ar}}\right), 140.6(\mathrm{Cq}), 159.1(\mathrm{Cq})$, $159.2(\mathrm{Cq}), 167.8(\mathrm{Cq}), 170.3(\mathrm{Cq}), 181.6(\mathrm{Cq}))$; IR (KBr) $\tilde{v} 1720(\mathrm{C}=\mathrm{O}), 1245 \mathrm{~cm}^{-1}(\mathrm{C}=\mathrm{S})$; EIMS $m / z 596\left(\mathrm{M}^{+}, 7\right), 561$ (45); HRMS (EI) calcd for $\mathrm{C}_{26} \mathrm{H}_{29} \mathrm{ClN}_{2} \mathrm{O}_{6} \mathrm{~S}_{3}: 596.0876$; found 596.0885.

General procedure for the synthesis of dithiafulvenes 6a-d and 7. Dimethyl or diethyl acetylenedicarboxylate $\mathbf{3 a - b}(36 \mathrm{mg} \mathbf{3 a}, 43 \mathrm{mg} \mathrm{3b}, 0.25 \mathrm{mmol})$ was added to a solution of 1,2dithiole-3-thione $\mathbf{2 a - b}$ (100 $\mathrm{mg} \mathbf{2 a}, 107 \mathrm{mg} \mathbf{2 b}, 0.25 \mathrm{mmol})$ in dry benzene $(5 \mathrm{~mL})$ under nitrogen and the mixture was refluxed for 1.5 hours. Then aniline $\mathbf{5 a}(58 \mathrm{mg}, 0.62 \mathrm{mmol})$, 2(diethylamino)ethanethiol $5 \mathbf{b}(83 \mathrm{mg}, 0.62 \mathrm{mmol})$ or pyrrolidine $(44 \mathrm{mg}, 0.62 \mathrm{mmol})$ in benzene (2 
$\mathrm{mL}$ ) was added at room temperature and the mixture was stirred for 1 hour. Then the solvent was evaporated under reduced pressure and the residue was purified by flash chromatography (silica 230-400 mesh, hexane to hexane/EtOAc 1:1).

Diethyl 6-[N-(2-phthalimidoethyl)- $N$-isopropyl]amino-6-( $N$-phenylamino)thiocarbonyl-1,4dithiafulvene-2,3-dicarboxylate 6a. $140 \mathrm{mg}, 89 \%$, red sticky solid (hexane/EtOAc); ${ }^{1} \mathrm{H}$ NMR $\left(400 \mathrm{MHz}, \mathrm{CDCl}_{3}\right) \delta 1.09-1.39(\mathrm{~m}, 12 \mathrm{H}), 3.40-3.48(\mathrm{~m}, 2 \mathrm{H}), 3.67$ (hept, $\left.J=6.4,1 \mathrm{H}\right), 3.82-3.91$ $(\mathrm{m}, 2 \mathrm{H}), 4.25-4.39(\mathrm{~m}, 4 \mathrm{H}), 7.12-7.37\left(\mathrm{~m}, 3 \mathrm{H}, \mathrm{H}_{\mathrm{Ar}}\right), 7.58-7.75\left(\mathrm{~m}, 6 \mathrm{H}, \mathrm{H}_{\mathrm{Ar}}\right), 10.60(\mathrm{~s}$, exch, $1 \mathrm{H}$, $\mathrm{NH}) ;{ }^{13} \mathrm{C} \mathrm{NMR}\left(100 \mathrm{MHz}, \mathrm{CDCl}_{3}, \mathrm{DEPT}\right) \delta 13.9\left(2 \mathrm{x} \mathrm{CH}_{3}\right), 21.0\left(\mathrm{CH}_{3}\right.$ isopropyl $), 24.1\left(\mathrm{CH}_{3}\right.$ isopropyl $)$, 38.6 $\left(\mathrm{CH}_{2}\right), 48.0\left(\mathrm{CH}_{2}\right), 51.1(\mathrm{CH}), 62.7\left(\mathrm{CH}_{2}\right), 122.4\left(\mathrm{CH}_{\mathrm{Ar}}\right), 123.1\left(\mathrm{CH}_{\mathrm{Ar}}\right), 125.7\left(\mathrm{CH}_{\mathrm{Ar}}\right), 127.3$ $(\mathrm{Cq}), 128.5\left(\mathrm{CH}_{\mathrm{Ar}}\right), 131.5(\mathrm{Cq}), 133.0\left(\mathrm{CH}_{\mathrm{Ar}}\right), 137.6(\mathrm{Cq}), 138.5(\mathrm{Cq}), 154.3(\mathrm{Cq}), 159.2(\mathrm{C}=\mathrm{O})$, $160.4(\mathrm{C}=\mathrm{O}), 168.0(2 \times \mathrm{C}=\mathrm{O}), 186.1(\mathrm{C}=\mathrm{S}) ; \mathrm{IR}(\mathrm{KBr}) \tilde{v} 3396,2979,1715(\mathrm{C}=\mathrm{O}), 1573,1433$, 1237(C=S), $1088 \mathrm{~cm}^{-1}$; MS $\left(\mathrm{FAB}^{+}\right) \mathrm{m} / z 625\left(\mathrm{M}^{+}, 100\right)$; HRMS (LSIMS) calcd for $\mathrm{C}_{30} \mathrm{H}_{31} \mathrm{~N}_{3} \mathrm{O}_{6} \mathrm{~S}_{3}$ : 625.1375; found 625.1367; Anal. Calcd for $\mathrm{C}_{30} \mathrm{H}_{31} \mathrm{~N}_{3} \mathrm{O}_{6} \mathrm{~S}_{3}$ : C, 57.58; H, 4.99; N, 6.72. Found: C, $57.64 ; \mathrm{H}, 5.10 ; \mathrm{N}, 6.58$.

\section{Dimethyl}

6-[N-(2-phthalimidoethyl)- $N$-isopropyl]amino-6-[2-(diethylamino)ethylmercapto]thiocarbonyl-1,4-dithiafulvene-2,3-dicarboxylate 6 b. $130 \mathrm{mg}$, 82\%, red sticky solid (hexane/EtOAc); ${ }^{1} \mathrm{H}$ NMR $\left(400 \mathrm{MHz}, \mathrm{C}_{6} \mathrm{D}_{5} \mathrm{Cl}\right) \delta 0.98(\mathrm{t}, J=7.2,6 \mathrm{H}), 1.09(\mathrm{~d}, J=6.5,3 \mathrm{H}), 1.37$ $(\mathrm{d}, J=6.5,3 \mathrm{H}), 2.48(\mathrm{q}, J=7.2,4 \mathrm{H}), 2.67-2.72(\mathrm{~m}, 2 \mathrm{H}), 3.30-3.36(\mathrm{~m}, 2 \mathrm{H}), 3.59-3.73(\mathrm{~m}, 3 \mathrm{H})$, $3.56(\mathrm{~s}, 3 \mathrm{H}), 3.62(\mathrm{~s}, 3 \mathrm{H}), 3.96-4.02(\mathrm{~m}, 2 \mathrm{H}), 7.20-7.32\left(\mathrm{~m}, 2 \mathrm{H}, \mathrm{H}_{\mathrm{Ar}}\right), 7.54-7.62\left(\mathrm{~m}, 2 \mathrm{H}, \mathrm{H}_{\mathrm{Ar}}\right) ;{ }^{13} \mathrm{C}$ NMR $\left(100 \mathrm{MHz}, \mathrm{C}_{6} \mathrm{D}_{5} \mathrm{Cl}, \mathrm{DEPT} \mathrm{CDCl}_{3}\right) \delta 11.9\left(2 \times \mathrm{CH}_{3}\right), 20.1\left(\mathrm{CH}_{3}\right), 23.0\left(\mathrm{CH}_{3}\right), 32.4\left(\mathrm{CH}_{2}\right)$, $38.3\left(\mathrm{CH}_{2}\right), 47.0\left(2 \times \mathrm{CH}_{2}\right), 50.3\left(\mathrm{CH}_{2}\right), 50.5\left(\mathrm{CH}_{2}\right), 53.3\left(\mathrm{CH}_{3}\right), 53.4\left(\mathrm{CH}_{3}\right), 54.0(\mathrm{CH}), 123.1$ $\left(\mathrm{CH}_{\mathrm{Ar}}\right), 131.4(\mathrm{Cq}), 132.0(\mathrm{Cq}), 133.4(\mathrm{Cq}), 133.8\left(\mathrm{CH}_{\mathrm{Ar}}\right), 136.1(\mathrm{Cq}), 160.3(2 \mathrm{x} \mathrm{C}=\mathrm{O}), 168.0(2 \mathrm{x}$ $\mathrm{C}=\mathrm{O}), 207.6(\mathrm{C}=\mathrm{S})$; IR $(\mathrm{KBr}) \tilde{v} 1710(\mathrm{C}=\mathrm{O}), 1435,1390,1245 \mathrm{~cm}^{-1}(\mathrm{C}=\mathrm{S}) ; \mathrm{MS}\left(\mathrm{FAB}^{+}\right) \mathrm{m} / z 638$ $\left(\mathrm{M}^{+}+1,100\right), 565$ (52), 174 (54); HRMS (LSIMS) calcd for $\left[\mathrm{C}_{28} \mathrm{H}_{35} \mathrm{~N}_{3} \mathrm{O}_{6} \mathrm{~S}_{4}+\mathrm{H}\right]^{+}: 638.1481$; 
found 638.1472; Anal. Calcd for $\mathrm{C}_{28} \mathrm{H}_{35} \mathrm{~N}_{3} \mathrm{O}_{6} \mathrm{~S}_{4}$ : C, 52.73; H, 5.53; N, 6.59. Found: C, 52.81; H, $5.61 ; \mathrm{N}, 6.50$.

Dimethyl 6-[N-(2-phthalimidoethyl)- $N-(2,2-$ dimethylpropyl)]amino-6-( $N$-phenylamino)thiocarbonyl-1,4-dithiafulvene-2,3-dicarboxylate 6c. $88 \mathrm{mg}, 56 \%$, red sticky solid (hexane/EtOAc); ${ }^{1} \mathrm{H}$ NMR $\left(400 \mathrm{MHz}, \mathrm{C}_{6} \mathrm{D}_{5} \mathrm{Cl}\right) \delta 0.94(\mathrm{~s}, 9 \mathrm{H}), 2.72(\mathrm{~d}, J=12.6,1 \mathrm{H}), 3.06(\mathrm{~d}, J=$ 12.6, 1H), 3.34-3.38 (m, 2H), $3.58(\mathrm{~s}, 3 \mathrm{H}), 3.63(\mathrm{~s}, 3 \mathrm{H}), 4.80-4.83(\mathrm{~m}, 2 \mathrm{H}), 7.03-7.09(\mathrm{~m}, 2 \mathrm{H}$, $\left.\mathrm{H}_{\mathrm{Ar}}\right)$, 7.19-7.28 (m, 3H, $\left.\mathrm{H}_{\mathrm{Ar}}\right)$, 7.51-7.54 (m, 2H, $\left.\mathrm{H}_{\mathrm{Ar}}\right), 8.00-8.02\left(\mathrm{~m}, 2 \mathrm{H}, \mathrm{H}_{\mathrm{Ar}}\right), 11.10(\mathrm{~s}$, exch, $1 \mathrm{H}$, $\mathrm{NH}) ;{ }^{13} \mathrm{C}-\mathrm{NMR}\left(100 \mathrm{MHz}, \mathrm{C}_{6} \mathrm{D}_{5} \mathrm{Cl}\right) \delta 28.6,33.2,37.4,53.2,54.9,67.3,123.1,128.5,132.4,133.8$, 134.2, 141.1, 159.6, 167.6, 170.2, 181.9; IR (KBr) $\tilde{v} 1709(\mathrm{C}=\mathrm{O}), 1432,1253 \mathrm{~cm}^{-1}(\mathrm{C}=\mathrm{S})$; MS $\left(\mathrm{FAB}^{+}\right) m / z 625\left(\mathrm{M}^{+}, 76\right), 533(49), 174(87), 147(100)$; HRMS (FAB ${ }^{+}$) calcd for $\mathrm{C}_{30} \mathrm{H}_{31} \mathrm{~N}_{3} \mathrm{O}_{6} \mathrm{~S}_{3}$ : 625.1375; found 625.1388; Anal. Calcd for $\mathrm{C}_{30} \mathrm{H}_{31} \mathrm{~N}_{3} \mathrm{O}_{6} \mathrm{~S}_{3}$ : C, 57.58; H, 4.99; N, 6.72. Found: C, $57.64 ; \mathrm{H}, 5.05 ; \mathrm{N}, 6.56$.

Diethyl

6-[N-(2-phthalimidoethyl)- $N$-(2,2-dimethylpropyl)]amino-6-( $N$-phenylamino)thiocarbonyl-1,4-dithiafulvene-2,3-dicarboxylate 6d. $88 \mathrm{mg}, 54 \%$, red sticky solid (hexane/EtOAc); ${ }^{1} \mathrm{H}$ NMR (400 MHz, $\left.\mathrm{CDCl}_{3}\right) \delta 1.00$ (s, 9H), 1.32-1.37 (m, 6H), 2.85 (d, $J=14.3$, $1 \mathrm{H}), 3.11(\mathrm{~d}, J=14.3,1 \mathrm{H}), 3.39-3.43(\mathrm{~m}, 2 \mathrm{H}), 3.83-3.87(\mathrm{~m}, 2 \mathrm{H}), 4.28-4.39(\mathrm{~m}, 4 \mathrm{H}), 7.17-7.30$ $\left(\mathrm{m}, 3 \mathrm{H}, \mathrm{H}_{\mathrm{Ar}}\right), 7.61-7.78\left(\mathrm{~m}, 6 \mathrm{H}, \mathrm{H}_{\mathrm{Ar}}\right), 10.85(\mathrm{~s}$, exch, $1 \mathrm{H}, \mathrm{NH}) ;{ }^{13} \mathrm{C} \mathrm{NMR}\left(100 \mathrm{MHz}, \mathrm{CDCl}_{3}\right) \delta$ $14.0,28.4,33.4,37.2,51.7,62.8,64.9,122.6,123.3,126.0,127.2,128.8,131.1,131.7,134.0$, 137.8, 138.5, 152.8, 159.3, 160.6, 167.9, 185.2; IR (KBr) $\tilde{v} 3434,3215,1778,1713(\mathrm{C}=\mathrm{O}), 1257$ $\mathrm{cm}^{-1}(\mathrm{C}=\mathrm{S}) ; \mathrm{MS}\left(\mathrm{FAB}^{+}\right) \mathrm{m} / z 653\left(\mathrm{M}^{+}, 100\right), 561(58)$; HRMS $\left(\mathrm{FAB}^{+}\right)$calcd for $\mathrm{C}_{32} \mathrm{H}_{35} \mathrm{~N}_{3} \mathrm{O}_{6} \mathrm{~S}_{3}$ : 653.1688; found 653.1697; Anal. Calcd for $\mathrm{C}_{32} \mathrm{H}_{35} \mathrm{~N}_{3} \mathrm{O}_{6} \mathrm{~S}_{3}$ : C, 58.78; H, 5.40; N, 6.43. Found: C, $58.84 ; \mathrm{H}, 5.49 ; \mathrm{N}, 6.36$.

Diethyl 6-[N-(2-phthalimidoethyl)- $N$-isopropyl]amino-6-(pyrrolidin-1-yl)thiocarbonyl-1,4dithiafulvene-2,3-dicarboxylate $7 .^{13} 0.13 \mathrm{~g}, 90 \%$, red crystals (hexane/EtOAc), mp 113-114 ${ }^{\circ} \mathrm{C}$; 
${ }^{1} \mathrm{H}$ NMR $\left(400 \mathrm{MHz}, \mathrm{CDCl}_{3}\right) \delta$ 1.22-1.40 (m, 12H), 2.05-2.11 (m, 4H), 2.87-2.95 (m, 2H), 3.40 (hept, $J=6.4,1 \mathrm{H}), 3.57-3.65(\mathrm{~m}, 2 \mathrm{H}), 3.89-3.99(\mathrm{~m}, 4 \mathrm{H}), 4.17-4.31(\mathrm{~m}, 4 \mathrm{H}), 7.65-7.81(\mathrm{~m}, 4 \mathrm{H}$, $\left.\mathrm{H}_{\mathrm{Ar}}\right) ;{ }^{13} \mathrm{C} \mathrm{NMR}\left(100 \mathrm{MHz}, \mathrm{CDCl}_{3}, \mathrm{DEPT}\right) \delta 14.2\left(2 \times \mathrm{CH}_{3}\right), 22.0\left(2 \times \mathrm{CH}_{3}\right), 25.5\left(2 \times \mathrm{CH}_{2}\right), 38.7$ $\left(\mathrm{CH}_{2}\right), 46.0\left(\mathrm{CH}_{2}\right), 52.9\left(2 \times \mathrm{CH}_{2}\right), 56.0(\mathrm{CH}), 62.7\left(\mathrm{CH}_{2}\right), 62.9\left(\mathrm{CH}_{2}\right), 123.4\left(\mathrm{CH}_{\mathrm{Ar}}\right), 127.0(\mathrm{Cq})$, $128.9(\mathrm{Cq}), 131.9(\mathrm{Cq}), 132.3(\mathrm{Cq}), 133.4(\mathrm{Cq}), 134.2\left(\mathrm{CH}_{\mathrm{Ar}}\right), 159.7(\mathrm{C}=\mathrm{O}), 160.5(\mathrm{C}=\mathrm{O}), 168.3(2$ $\mathrm{x} \mathrm{C}=\mathrm{O}), 190.7(\mathrm{C}=\mathrm{S})$; IR $(\mathrm{KBr}) \tilde{v} 2968,2870,1715(\mathrm{C}=\mathrm{O}), 1586,1391,1240(\mathrm{C}=\mathrm{S}), 1018 \mathrm{~cm}^{-1}$; MS $\left(\mathrm{FAB}^{+}\right) m / z 603\left(\mathrm{M}^{+}, 100\right)$; HRMS $\left(\mathrm{FAB}^{+}\right)$calcd for $\mathrm{C}_{28} \mathrm{H}_{33} \mathrm{~N}_{3} \mathrm{O}_{6} \mathrm{~S}_{3}$ : 603.1531; found 603.1530; Anal. Calcd for $\mathrm{C}_{28} \mathrm{H}_{33} \mathrm{~N}_{3} \mathrm{O}_{6} \mathrm{~S}_{3}$ : C, 55.70; H, 5.51; N, 6.96. Found: C, 55.63; H, 5.56; N, 6.90; Crystal data for 7, $\mathrm{C}_{28} \mathrm{H}_{33} \mathrm{~N}_{3} \mathrm{O}_{6} \mathrm{~S}_{3}, M=603.75$, monoclinic, $\mathrm{P} 2(1) / \mathrm{c}, a=16.942(2) \AA, b=$ 14.3803(18) $\AA, c=37.907(5) \AA, \alpha=90^{\circ}, \beta=101.603(3)^{\mathrm{o}}, \gamma=90^{\circ} ; V=9046.8(19) \AA^{3}, Z=12$, $D_{\text {calc }}=1.330 \mathrm{gcm}^{-1}, \mu\left(\mathrm{Mo}-\mathrm{K}_{\alpha}\right)=0.291 \mathrm{~mm}^{-1}$. Red needle, $(0.30 \times 0.20 \times 0.20) \mathrm{mm}^{3} .66244$ measured reflections, 15913 independent $\left(\mathrm{R}_{\text {int }}=0.0916\right), 7448$ observed $(I>2 \sigma(I)) . R_{1}=0.0708$, $\mathrm{w} R_{2}=0.1894$ (all data), CCDC 1010580.

Acknowledgments. We gratefully acknowledge financial support from the Ministerio de Economía y Competitividad, Spain (Project CTQ2012-31611), Junta de Castilla y León, Consejería de Educación y Cultura y Fondo Social Europeo (Project BU246A12-1) and the European Commission, Seventh Framework Programme (Project SNIFFER FP7-SEC-2012312411). We also thank Marta Mansilla and Dr. Jacinto J. Delgado (SCAI-Universidad de Burgos) for the X-ray determinations. This paper is dedicated to Dr. Stefano Marcaccini who passed away the $1^{\text {st }}$ October 2012 .

Supporting Information Available. Copies of ${ }^{1} \mathrm{H}$ and ${ }^{13} \mathrm{C}$ NMR of the products, X-Ray diffraction structures and coordinates of all stationary points for the calculated structures. This material is available free of charge via the Internet at http://pubs.acs.org.

\section{References:}


(1) Review: Fischer, G. Adv. Heterocycl. Chem. 2013, 109, 1-90.

(2) (a) Bhattacharyya, S.; Zhou, H.; Seiner, D. R.; Gates, K. S. Bioorg. Med.Chem. 2010, 18, 5945-5949; (b) Tazzari, V. ; Cappelletti, G.; Casagrande, M.; Perrino, E.; Renzi, L.; Del Soldato, P.; Sparatore, A. Bioorg. Med. Chem. 2010, 18, 4187-4194; (c) Munday, R.; Zhang, Y. ; Paonessa, J. D.; Munday, C. M.; Wilkins, A. L.; Babu, J. J. Med. Chem. 2010, 53, 47614767; reviews: (d) Magesh, S.; Chen, Y.; Hu, L. Med. Res. Rev. 2012, 32, 687-726; (e) Wilson, A. J.; Kerns, J. K.; Callahan, J. F.; Moody, C. J. J. Med. Chem. 2013, 56, 7463-7476.

(3) Chen, P.; Luo, Y.; Hai, L.; Qian, S.; Wu, Y. Eur. J. Med. Chem. 2010, 45, 3005-3010.

(4) Review: Kashfi, K.; Olson, K. R. Biochem. Pharmacol. 2013, 85, 689-703.

(5) Review: Jacob, C.; Battaglia, E.; Burkholz, T.; Peng, D.; Bagrel, D.; Montenarh, M. Chem. Res. Toxicol. 2012, 25, 588-604.

(6) See for example: Fuertes, P.; García-Valverde, M.; Cuevas, J. V.; Díaz de Greñu, B.; Rodríguez, T.; Rojo, J.; Torroba, T. J. Org. Chem. 2014, 79, 2213-2225.

(7) Reviews: a) Saito, G.; Yoshida, Y. Chem. Rec. 2011, 11, 124-145; (b) Misaki, Y. Sci. Technol. Adv. Mater. 2009, 10, 024301 (22 pp).

(8) (a) Hopf, H.; Sherburn, M. S. Angew. Chem. Int. Ed. 2012, 51, 2298-2338; (b) Kato, S.; Diederich, F. Chem. Commun. 2010, 46, 1994-2006; (c) Shoji, T.; Ito, S.; Okujima, T.; Morita, N. Org. Biomol. Chem. 2012, 10, 8308-8313; (d) Guo, K.; Yan, K.; Lu, X.; Qiu, Y.; Liu, Z.; Sun, J.; Yan, F.; Guo, W.; Yang, S. Org. Lett. 2012, 14, 2214-2217; (e) Bouit, P.-A.; Villegas, C.; Delgado, J. L.; Viruela, P. M.; Pou-Amerigo, R.; Orti, E.; Martin, N. Org. Lett. 2011, 13, 604-607.

(9) (a) Canevet, D.; Salle, M.; Zhang, G.; Zhang, D.; Zhu, D. Chem. Commun. 2009, 2245-2269;

(b) Martin, N. ; Sanchez, L.; Herranz, M. A.; Illescas, B.; Guldi, D. M. Acc. Chem. Res. 2007, 40, 1015-1024; (c) Kusamoto, T.; Takada, K.; Sakamoto, R.; Kume, S.; Nishihara, H.; Inorg. 
Chem. 2012, 51, 12102-12113; (d) Naito, T.; Karasudani, T.; Mori, S.; Ohara, K.; Konishi, K.; Takano, T.; Takahashi, Y.; Inabe, T.; Nishihara, S.; Inoue, K. J. Am. Chem. Soc. 2012, 134, 18656-18666; (e) Santos, J.; Illescas, B. M.; Martin, N.; Adrio, J.; Carretero, J. C.; Viruela, R.; Orti, E.; Spanig, F.; Guldi, D. M. Chem. Eur. J. 2011, 17, 2957-2964.

(10) (a) Massue, J.; Bellec, N.; Guerro, M.; Bergamini, J.-F.; Hapiot, P.; Lorcy, D. J. Org. Chem. 2007, 72, 4655-4662; (b) Dolder, S.; Liu, S.-X.; Le Derf, F.; Salle, M.; Neels, A.; Decurtins, S. Org. Lett. 2007, 9, 3753-3756.

(11) Recent examples: (a) Lorcy, D.; Bellec, N.; Fourmigue, M.; Avarvari, N. Coord. Chem. Rev. 2009, 253, 1398-1438; (b) De Bonneval, B. G.; Ching, K. I. M.-C.; Alary, F.; Bui, T.-T.; Valade, L. Coord. Chem. Rev. 2010, 254, 1457-1467.

(12) Review: (a) Garcia-Valverde, M.; Torroba, T. Eur. J. Org. Chem. 2006, 849-861; many examples in: (b) Andrada, D. M.; Granados, A. M.; Sola, M.; Fernandez, I. Organometallics 2011, 30, 466-476; recent examples: (c) Fuertes, P.; Moreno, D.; Cuevas, J. V.; GarciaValverde, M.; Torroba, T. Chem. Asian J. 2010, 5, 1692-1699; (d) Granados, A. M.; Fracaroli, A. M.; de Rossi, R. H.; Fuertes, P.; Torroba, T. Chem. Commun. 2008, 483-485.

(13) Garcia-Valverde, M.; Pascual, R.; Torroba, T. Org. Lett. 2003, 5, 929-932.

(14) See for example: (a) Alfonso, I.; Burguete, M. I.; Luis, S. V. J. Org. Chem. 2006, 71, 22422250; (b) Xia, J. L.; Liu, S. H.; Cozzi, F.; Mancinelli, M.; Mazzanti, A. Chem. Eur. J. 2012, 18, 3611-3620; (c) Lunazzi, L.; Mancinelli, M.; Mazzanti, A. J. Org. Chem. 2012, 77, 3373-3380; (d) Lazareva, N. F.; Albanov, A. I.; Shainyan, B. A.; Kleinpeter, E. Tetrahedron 2012, 68, 1097-1104; (e) Lazareva, N. F.; Shainyan, B. A.; Schilde, U.; Chipanina, N. N.; Oznobikhina, L. P.; Albanov, A. I.; Kleinpeter, E. J. Org. Chem. 2012, 77, 2382-2388 (f) Ambrogi, M.; Ciogli, A.; Mancinelli, M.; Ranieri, S.; Mazzanti, A. J. Org. Chem. 2013, 78, 
3709-3719; (g) Szatmári, I.; Heydenreich, M.; Koch, A.; Fülöp, F.; Kleinpeter, E. Tetrahedron 2013, 69, 7455-7465.

(15) See for example: (a) Lunazzi, L.; Mancinelli, M.; Mazzanti, A.; Lepri, S.; Ruzziconi, R.; Schlosser, M. Org. Biomol. Chem. 2012, 10, 1847-1855; (b) Mazzanti, A.; Chiarucci, M.; Bentley, K. W.; Wolf, C. J. Org. Chem. 2014, 79, 3725-3730.

(16) See for example: (a) Alfonso, I.; Burguete, M. I.; Galindo, F.; Luis, S. V.; Vigara, L. J. Org. Chem. 2007, 72, 7947-7956; (b) Dial, B. E.; Rasberry, R. D.; Bullock, B. N.; Smith, M. D.; Pellechia, P. J.; Profeta, Jr., S.; Shimizu, K. D. Org. Lett. 2011, 13, 244-247; (c) Dial, B. E.; Pellechia, P. J.; Smith, M. D.; Shimizu, K. D. J. Am. Chem. Soc. 2012, 134, 3675-3678.

(17) See for example: (a) Aubin, L. B.; Wagner, T. M.; Thoburn, J. D.; Kesler, B. S.; Hutchison, K. A.; Schumaker, R. R.; Parakka, J. P. Org. Lett. 2001, 3, 3413-3416; (b) Bongini, A.; Barbarella, G.; Favaretto, L.; Sotgiu, G.; Zambianchi, M.; Casarini, D. Tetrahedron 2002, 58, 10151-10158; (c) Wade, E. O.; Valiulin, R. A.; Ruybal, L. A.; Kutateladze, A. G. Org. Lett. 2006, 8, 5121-5124; (d) Akutagawa, T.; Sato, D.; Ye, Q.; Endo, T.; Noro, S.-I.; Takeda, S.; Nakamura, T. Dalton Trans. 2010, 39, 8219-8227.

(18) Reaction mechanisms: (a) Rees, C. W.; White, A. J. P.; Williams, D. J.; Rakitin, O. A.; Marcos, C. F.; Polo, C.; Torroba, T. J. Org. Chem. 1998, 63, 2189-2196; (b) Rees, C. W.; White, A. J. P.; Williams, D. J.; Rakitin, O. A.; Konstantinova, L. S.; Marcos, C. F.; Torroba, T. J. Org. Chem. 1999, 64, 5010-5016; see also (c) Rees, C. W.; Rakitin, O. A.; Marcos, C. F.; Torroba, T. J. Org. Chem. 1999, 64, 4376-4380.

(19) Budzelaar, P. H. M. IvorySoft 2004, Adept Scientific Plc, Amor Way, Letchworht, Herts, SG6 1ZA UK.

(20) Groom, C. R.; Allen, F. H. Angew. Chem. Int. Ed. 2014, 53, 662-671. 
(21) (a) Steiner, T. Angew. Chem. Int. Ed. 2002, 41, 49-76; (b) Jeffrey, G. A., An Introduction to Hydrogen Bonding, Oxford University Press, Oxford, 1997.

(22) Iwamatsu, M.; Kominami, T.; Ueda, K.; Sugimoto, T.; Tada, T.; Nishimura, K.-I.; Adachi, T.; Fujita, H.; Guo, F.; Yokogawa, S.; Yoshino, H.; Murata, K.; Shiro, M. J. Mater. Chem. 2001, 11, 385-391.

(23) Reviews: (a) Minkin, V. I.; Minyaev, R. M. Chem. Rev. 2001, 101, 1247-1265; (b) Milov, A. A.; Minyaev, R. M.; Minkin, V. I. J. Phys. Chem. A 2011, 115, 12973-12982; (c) Minkin, V. I. Russ. Chem. Bull. Int. Ed. 2012, 61, 1265-1290.

(24) See for example: (a) Lekin, K. Phan, H.; Winter, S. M.; Wong, J. W. L.; Leitch, A. A.; Laniel, D.; Yong, W.; Secco, R. A.; Tse, J. S.; Desgreniers, S.; Dube, P. A.; Shatruk, M.; Oakley, R. T. J. Am. Chem. Soc. 2014, 136, 8050-8062; (b) Chuang, Y.-C.; Li, Y.-W.; Hsu, I.-J.; Lee, G.-H.; Wang, Y. Inorg. Chem. 2013, 52, 10958-10967; (c) Rasovic, A.; Koch, A.; Kleinpeter, E.; Markovic, R. Tetrahedron 2013, 69, 10849-10857; (d) Atsumi, T.; Abe, T.; Akiba, K.-Y.; Nakai, H. Bull. Chem. Soc. Jpn. 2010, 83, 520-529.

(25) See for example: (a) Tse, J. S.; Leitch, A. A.; Yu, X.; Bao, X.; Zhang, S.; Liu, Q.; Jin, C.; Secco, R. A.; Desgreniers, S.; Ohishi, Y.; Oakley, R. T. J. Am. Chem. Soc. 2010, 132, 48764886; (b) Navarrete-Vazquez, G.; Alaniz-Palacios, A.; Tlahuextl, M.; Bernal-Uruchurtuc, M.; Tlahuext, H. CrystEngComm. 2012, 14, 1256-1263; (c) Mancini, A.; Pala, L.; Aragoni, M. C.; Arca, M.; Devillanova, F. A.; Hursthouse, M. B.; Light, M. E.; Skabara, P. J.; Bricklebank, N. Eur. J. Inorg. Chem. 2012, 2373-2380; (d) Iwaoka, M.; Isozumi, N. Molecules 2012, 17, 7266-7283; (e) Félix-Sonda, B. C.; Rivera-Islas, J.; Herrera-Ruiz, D.; Morales-Rojas, H.; Höpfl, H. Cryst. Growth Des. 2014, 14, 1086-1102.

(26) Thioketone: (a) Beer, R. J. S.; Frew, D.; Johnson, P. L.; Paul, I. C. J. Chem. Soc. D, 1970, 154-155; thiocarbonyl chloride: (b) Ogurtsov, V. A.; Rakitin, O. A.; Rees, C. W.; Smolentsev, 
A. A.; Belyakov, P. A.; Golovanov, D. G.; Lyssenko, K. A. Org. Lett. 2005, 7, 791-794; thioaldehyde: (c) Frere, P.; Belyasmine, A.; Gouriou, Y.; Jubault, M.; Gorgues, A.; Duguay, G.; Wood, S.; Reynolds, C. D.; Bryce, M. R. Bull. Soc. Chim. Fr. 1995, 132, 975-984.

(27) Ketones: (a) Bulgarovska, I.; Sobolev, A.; Zavodnik, V.; Khodorkovsky, V.; Neilands, O. Latv. PSR, Zinat. Akad. Vestis, Khim. Ser. 1988, 349; (b) Frere, P.; Belyasmine, A.; Gorgues, A.; Duguay, G.; Boubekeur, K.; Batail, P. Tetrahedron Lett. 1993, 34, 4519-4522; (c) Bryce, M. R.; Chalton, M. A.; Batsanov, A. S.; Lehmann, C. W.; Howard, J. A. K. J. Chem. Soc. Perkin Trans. 2, 1996, 2367-2371; esters: (d) Nakatsu, K.; Yoshie, N.; Yoshioka, H.; Nogami, T.; Shirota, Y.; Shimizu, Y.; Uemiya, T.; Yasuda, N. Mol. Cryst. Liq. Cryst. 1990, 182A, 5969; (e) Aitken, R. A.; Ferguson, G.; Raut, S. V. Chem. Commun. 1991, 812-814; (f) Mono, S.; Pritzkow, H.; Sundermeyer, W. Chem. Ber. 1993, 126, 2111-2118; (g) Guerro, M.; Lorcy, D. Tetrahedron Lett. 2005, 46, 5499-5502; (h) Zhao, Y.-L.; Zhang, W.; Zhang, J.-Q.; Liu, Q. Tetrahedron Lett. 2006, 47, 3157-3159; very hindered esters: (i) Kuchenbeiser, G.; Soleilhavoup, M.; Donnadieu, B.; Bertrand, G. Chem. Asian J. 2009, 4, 1745-1750; (j) Busetto, L.; Marchetti, F.; Zacchini, S.; Zanotti, V. J. Organomet. Chem. 2011, 696, 40514056.

(28) Moore, A. J.; Bryce, M. R.; Batsanov, A. S.; Green, A.; Howard, J. A. K.; McKervey, M. A.; McGuigan, P.; Ledoux, I.; Orti, E.; Viruela, R.; Viruela, P. M.; Tarbit, B. J. Mater. Chem. 1998, $8,1173-1184$.

(29) (a) Fulmer, G. R.; Miller, A. J. M.; Sherden, N. H.; Gottlieb, H. E.; Nudelman, A.; Stoltz, B. M.; Bercaw, J. E.; Goldberg, K. I. Organometallics 2010, 29, 2176-2179; (b) Gottlieb, H. E.; Kotlyar, V.; Nudelman, A. J. Org. Chem. 1997, 62, 7512-7515.

(30) Becke, A. D. J. Chem. Phys. 1993, 98, 5648-5652.

(31) Lee, C. T.; Yang, W. T.; Parr, R. G. Phys. Rev. B 1988, 37, 785-789. 
(32) Frisch, M. J.; Trucks, G. W.; Schlegel, H. B.; Scuseria, G. E.; Robb, M. A.; Cheeseman, J. R.; Montgomery, J., J. A.; Vreven, T.; Kudin, K. N.; Burant, J. C.; Millam, J. M.; yengar, S. S.; Tomasi, J.; Barone, V.; Mennucci, B.; Cossi, M.; Scalmani, G.; Rega, N.; Petersson, G. A.; Nakatsuji, H.; Hada, M.; Ehara, M.; Toyota, K.; Fukuda, R.; Hasegawa, J.; Ishida, M.; Nakajima, T.; Honda, Y.; Kitao, O.; Nakai, H.; Klene, M.; Li, X.; Knox, J. E.; Hratchian, H. P.; Cross, J. B.; Adamo, C.; Jaramillo, J.; Gomperts, R.; Stratmann, R. E.; Yazyev, O.; Austin, A. J.; Cammi, R.; Pomelli, C.; Ochterski, J. W.; Ayala, P. Y.; Morokuma, K.; Voth, G. A.; Salvador, P.; Dannenberg, J. J.; Zakrzewski, V. G.; Dapprich, S.; Daniels, A. D.; Strain, M. C.; Farkas, O.; Malick, D. K.; Rabuck, A. D.; Raghavachari, K.; Foresman, J. B.; Ortiz, J. V.; Cui, Q.; Baboul, A. G.; Clifford, S.; Cioslowski, J.; Stefanov, B. B.; Liu, G.; Liashenko, A.; Piskorz, P.; Komaromi, I.; Martin, R. L.; Fox, D. J.; Keith, T.; Al-Laham, M. A.; Peng, C. Y.; Nanayakkara, A.; Challacombe, M.; Gill, P. M. W.; Johnson, B.; Chen, W.; Wong, M. W.; Gonzalez, C.; Pople, J. A.; Gaussian 03, Revision C.02 ed.; Gaussian, Inc.: Wallingford, CT, 2004.

(33) (a) Barone, V.; Cossi, M.; Tomasi, J. J. Chem. Phys. 1997, 107, 3210-3221; (b) Cossi, M.; Barone, V.; Cammi, R.; Tomasi, J. Chem. Phys. Lett. 1996, 255, 327-335; (c) Tomasi, J.; Mennucci, B.; Cammi, R. Chem. Rev. 2005, 105, 2999-3093; (d) Tomasi, J.; Persico, M. Chem. Rev. 1994, 94, 2027-2094.

(34) (a) Reed, A. E.; Curtiss, L. A.; Weinhold, F. Chem. Rev. 1988, 88, 899-926; (b) Glendening, E. D.; Reed, A. E.; Carpenter, J. E.; Weinhold, F. in NBO Version 3.1.

(35) SMART diffractometer control software, Bruker Analytical X-ray Instruments Inc., Madison, WI, 1998.

(36) SAINT integration software, Siemens Analytical X-ray Instruments Inc., Madison, WI, 1994. 
(37) Sheldrick, G. M. SADABS: A program for absorption correction with the Siemens SMART system; University of Göttingen: Germany, 2001.

(38) SHELXTL program system version 5.1; Bruker Analytical X-ray Instruments Inc., Madison, WI, 1998.

(39) International Tables for Crystallography, Kluwer, Dordrecht, 1992, vol. C. 